\title{
Late Neogene chronology: New perspectives in high-resolution stratigraphy
}

\author{
W. A. Berggren Department of Geology and Geophysics, Woods Hole Oceanographic Institution, Woods Hole, \\ Massachusetts 02543 \\ $\left.\begin{array}{l}\text { F. J. Hilgen } \\ \text { C. G. Langereis }\end{array}\right\}$ Institute of Earth Sciences, Utrecht University, Budapestlaan 4, 3584 CD Utrecht, The Netherlands \\ D. V. Kent Lamont-Doherty Earth Observatory of Columbia University, Palisades, New York 10964 \\ J. D. Obradovich Isotope Geology Branch, U.S. Geological Survey, Denver, Colorado 80225 \\ Isabella Raffi Facolta di Scienze MM.FF.NN, Universita "G. D'Annunzio", "Chieti", Italy \\ M. E. Raymo Department of Earth, Atmospheric and Planetary Sciences, Massachusetts Institute of Technology, \\ Cambridge, Massachusetts 02139 \\ N. J. Shackleton Godwin Laboratory of Quaternary Research, Free School Lane, Cambridge University, \\ Cambridge CB2 3RS, United Kingdom
}

\section{ABSTRACT}

We present an integrated geochronology for late Neogene time (Pliocene, Pleistocene, and Holocene Epochs) based on an analysis of data from stable isotopes, magnetostratigraphy, radiochronology, and calcareous plankton biostratigraphy. Discrepancies between recently formulated astronomical chronologies and magnetochronologies for the past 6 m.y. have been resolved on the basis of new, high-precision $\mathrm{Ar} / \mathrm{Ar}$ ages in the younger part of this interval, the so-called Brunhes, Matuyama, and Gauss Epochs (= Chrons C1n-C2An; 0-3.58 Ma), and revised analysis of sea floor anomalies in the Pacific Ocean in the older part, the so-called Gilbert Epoch (= Chron C2Ar-C3r; 3.58-5.89 Ma). The magneto- and astrochronologies are now concordant back to the Chron C3r/C3An boundary at $5.89 \mathrm{Ma}$.

The Neogene (Miocene, Pliocene, Pleistocene, and Holocene) and Paleogene are treated here as period/system subdivisions of the Cenozoic Era/Erathem, replacements for the antiquated terms Tertiary and Quaternary. The boundary between the Miocene and Pliocene Series (Messinian/Zanclean Stages), whose global stratotype section and point (GSSP) is currently proposed to be in Sicily, is located within the reversed interval just below the Thvera (C3n.4n) Magnetic Polarity Subchronozone with an estimated age of 5.32 Ma. The Pliocene/Pleistocene boundary, whose GSSP is located at Vrica
(Calabria, Italy), is located near the top of the Olduvai (C2n) Magnetic Polarity Subchronozone with an estimated age of 1.81 Ma. The 13 calcareous nannoplankton and 48 planktonic foraminiferal datum events for the Pliocene, and 12 calcareous nannoplankton and 10 planktonic foraminiferal datum events for the Pleistocene, are calibrated to the newly revised late Neogene astronomical/geomagnetic polarity time scale.

\section{INTRODUCTION}

The past decade has witnessed a significant improvement in the precision and accuracy of late Neogene geochronology. This has been achieved through the merging of improved radiochronologic dating techniques and astronomical tuning methods with the already familiar and classical $\mathrm{K}-\mathrm{Ar}$ method and geomagnetic polarity time scale (GPTS). The application of new techniques to old problems in geochronology, however, has resulted in a paradox; namely, discrepancies between radiometrically based and astronomically based time scales for the later part of the Neogene. It is a consideration of these problems (and their resolution) that forms the focus of this paper.

This study resulted from a request in 1991 by M. B. Cita (University of Milan and chair of the International Union of Geological Sciences Subcommission on Neogene Stratigraphy) to one of us (Berggren) to chair a working group with the task of investigating and resolving the age disagreements in the then-nascent late Neogene chronologic schemes being developed by means of astronomical/climatic proxies (Hilgen, 1987; Hilgen and Langereis, 1988, 1989; Shackleton et al., 1990) and the classical radiometric age calibration of the GPTS (Mankinen and Dalrymple, 1979). Accordingly, a working group was established (refer to authorship of this paper), assignments made, and the work initiated. The extended period required to complete this work reflects the intense activity in the field of Neogene geochronology during the past $5 \mathrm{yr}$ and, in particular, resolution of the apparent discrepancies between the astronomical time scale and GPTS in 1993. This resolution was achieved primarily by means of new, high-precision $\mathrm{Ar} / \mathrm{Ar}$ ages on the younger part of the stratigraphic interval treated here and by means of revised interpretations of sea floor anomaly patterns in the Pacific Ocean in the older part of the Pliocene-Pleistocene record.

In this paper we review the historical framework and recent evolution of studies in magnetostratigraphy, isotopic radiochronology, and astrochronology on late Neogene geochronology. We then discuss the chronostratigraphic framework of the late Neogene and conclude with a tabulation of regional and global biostratigraphic datum events that have been calibrated to the newly proposed astro-magneto-radiochronology.

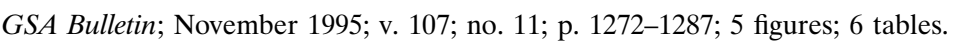




\section{ASTROCHRONOLOGY}

When the first deep-sea sediment $\delta^{18} \mathrm{O}$ records were presented by Emiliani (1955), he proposed that the quasi-cyclic variations in $\delta^{18} \mathrm{O}$ were due to astronomical forcing at the $41000 \mathrm{yr}$ tilt frequency. Although this has proven to be the case for the interval prior to 1 m.y. B.P. (Pisias and Moore, 1981; Ruddiman et al., 1986), better time control (Shackleton and Opdyke, 1973; Hays et al., 1976) demonstrated that climate records since then have been dominated by a 100000 yr cycle, although the shorter orbital cycles of tilt and precession are also preserved. The first step toward astrochronology was taken by Hays et al. (1976), who proposed that a modest adjustment to their initial time scale, well within geological constraints, would bring the peak variance of the obliquity cycles to exactly the same frequency calculated for obliquity by astrophysicists (i.e., $41000 \mathrm{yr}$ ). Moreover, after making this adjustment they found improved agreement between the shorter cycles and the orbital precessional frequencies at 19000 and $23000 \mathrm{yr}$. Thus, the method of "tuning" time scales was established.

By the middle 1980s, the large number of oxygen isotope records that had been generated were being used to further refine the "orbital" time scale (Prell et al., 1986; Pisias et al., 1984; Imbrie et al. 1984; Martinson et al., 1987), which, for the past $300000 \mathrm{yr}$, was proposed to be accurate to within $5000 \mathrm{yr}$ (Martinson et al., 1987). The astronomically calibrated time scale was extended to ca. 800000 yr B.P., still without generating any conflict with published geological constraints (Imbrie et al., 1984). These time scales proved extremely popular because they proposed ages for many characteristic features of the late Pleistocene $\delta^{18} \mathrm{O}$ record that are easily recognizable in deep-sea records (e.g., isotopic stages; Fig. 1).

Initial attempts at extending the orbital chronology back to the Pliocene (Pisias and Moore, 1981; Williams et al., 1988) were hampered by the relatively poor quality of the available core material. The development of the hydraulic piston corer by the Deep Sea Drilling Project, which allowed the recovery of continuous, high-sedimentation-rate sections, led to the generation of continuous, high-resolution isotopic records back to the middle Pliocene (and by now back to the Miocene). Using a continuous and orbitally tuned $\delta^{18} \mathrm{O}$ record from Deep Sea Drilling Project Site 607, Ruddiman et al. (1989) and Raymo et al. (1989) recalcu-
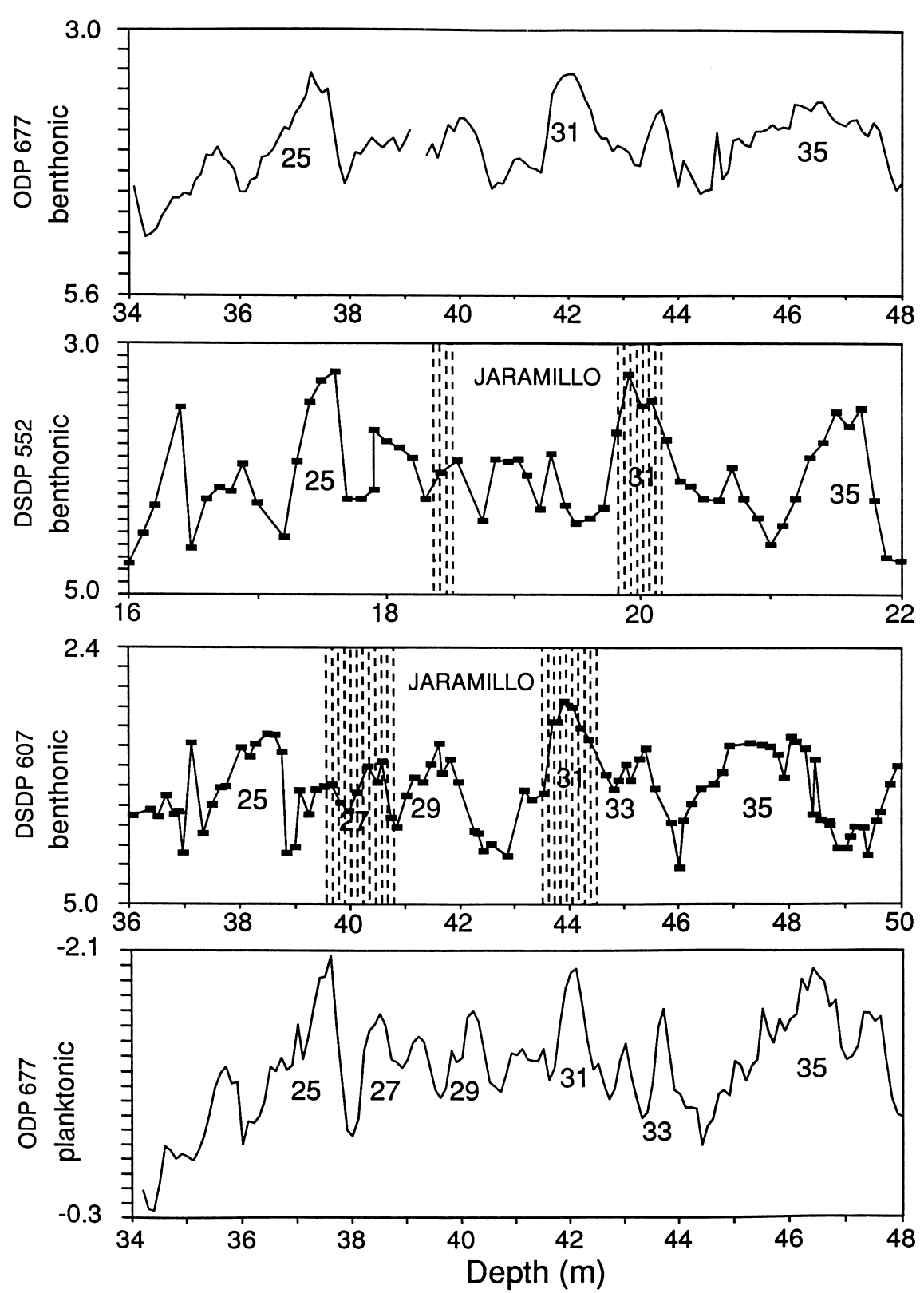

Figure 1. Oxygen isotope records from Deep Sea Drilling Project Sites 552A and 607, and Ocean Drilling Program Site 677, for the interval spanning isotope stages 24-35. Shaded intervals indicate depth range within which the Jaramillo magnetic reversals (top and bottom) fall in Sites 552 and 607 (after Shackleton et al., 1990).

lated the ages of magnetic reversals back to the top of the Gauss Chron. Once again, the study posed no serious conflicts with prior radioisotopic estimates other than a significantly shorter Olduvai event (170 $000 \mathrm{yr}$ as compared with the published duration of $220000 \mathrm{yr}$ ).

Shortly after this, a "radical" orbital time scale was proposed, which required a significant $(\approx 6 \%)$ adjustment to the published ages of the Pliocene-Pleistocene magnetic reversals (Shackleton et al., 1990; hereafter SBP90). In favor of the SBP90 time scale was the significant improvement in the coherency of the planktonic isotopic records with the highly modulated record of orbital precession. Hilgen (1991a), simultaneously examining Pliocene sedimentary sections in southern Italy, also proposed an astronomical chronology with the age of the Matuyama/Gauss boundary $6 \%$ older than the accepted value. 
The orbitally tuned time scale of SBP90 was based on the premise that one can correlate specific cycles in $\delta^{18} \mathrm{O}$ records to specific well-dated orbital variations. The greatest potential for error in such an exercise arises from the possibility that one might not recognize all the orbitally forced "cycles" in the sedimentary record, either because of natural sedimentation rate perturbations or because of a hiatus due to natural causes or the coring process. The possibility of overlooking a cycle increases in the older sections where fewer high-resolution records exist for intercomparison. By concentrating on two records which had been doublecored, SBP90 were able to avoid problems due to drilling. Detailed comparisons between the two isotope records, one from the Pacific and one from the Atlantic, suggested that neither of the cores had any obvious hiatuses above 2.6 Ma.

To correlate the isotopic climatic cycles to orbital cycles, SBP90 first established that the $0.9 \mathrm{~m}$ cycle and the $1.6 \mathrm{~m}$ cycles apparent in the Ocean Drilling Program (ODP) Site 677 isotopic record reflected variations in climate at the precessional and obliquity frequencies. The $0.9 \mathrm{~m}$ cycles were most obvious in the planktonic $\delta^{18} \mathrm{O}$ record (Fig. 1D), presumably because they reflect sea-surface temperature or precipitation variations at the equator, a region where precession dominates incoming solar radiation. As the precessional signal is strongly modulated by eccentricity, SBP90 focused on extracting and correlating this component of the planktonic isotopic record to the inferred orbital forcing. The correlation was made by matching the modulation of the isotopic record at this frequency, determined by statistically filtering the data, to that observed in the precessional signal (see SBP90 for detailed discussion of the methodology). This strategy clearly was better than working with the benthic isotope records (Figs. 1A-1C), which are dominated by the poorly modulated obliquity signal. While it is fairly straightforward to identify obliquity cycles, it is difficult, without the benefit of a strongly modulated signal, to be certain of the exact match into the orbital obliquity record.

By using the coherency of the precessional signal as their guide, SBP90 were able to show that the previous orbital chronology of Ruddiman et al. (1989) missed identifying two obliquity cycles in the early Brunhes and early Pleistocene sections of the record, in part because they accepted the literature age for the Matuyama/Brunhes boundary as being essentially correct. The SBP90 time

\begin{tabular}{|c|c|}
\hline Stage* & $\begin{array}{c}\text { Magnetic } \\
\text { reversal }\end{array}$ \\
\hline Brunhes/Matuyama & 19 \\
\hline Jaramillo $\mathrm{T}$ & 27 \\
\hline Jaramillo B & 31 \\
\hline Olduvai T & $63-64$ \\
\hline Olduvai B & $71-72$ \\
\hline Gauss/Matuyama & $103-104$ \\
\hline Kaena T & G21-G22 \\
\hline Kaena B & K3-KM2 \\
\hline Mammoth $\mathrm{T}$ & KM6 \\
\hline Mammoth B & MG1 \\
\hline Gauss/Gilbert & MG6-Gi1 \\
\hline Cochiti T & $\mathrm{Co1}-\mathrm{Co} 2$ \\
\hline Cochiti B & CN1 \\
\hline Nunivak T & N1-N2 \\
\hline Nunivak B & N7-N8 \\
\hline Sidufjall T & $\mathrm{Si} 1-\mathrm{Si} 2$ \\
\hline Sidufjall B & Si6 \\
\hline Thvera T & $\mathrm{T} 1$ \\
\hline Thvera B & TG2 \\
\hline \multicolumn{2}{|c|}{$\begin{array}{l}\text { *Oxygen isotope stage } \\
\text { designations after Ruddiman et } \\
\text { al. (1989), Raymo et al. (1989), } \\
\text { and Shackleton et al. (1995). }\end{array}$} \\
\hline
\end{tabular}

scale results in a downward (older) revision of ages (by $\approx 5 \%-7 \%$ ) for the magnetic reversals, biostratigraphic datums, and oxygen isotopic stages contained within the stratigraphic record of the past 3.5 m.y. In particular, one can use oxygen isotope stratigraphy to identify the stratigraphic level of magnetic reversals in cores without magnetic data (e.g. the Jaramillo Subchron in Fig. 1; Table 1). Clearly, the assignment of accurate ages to the characteristic features of the global $\delta^{18} \mathrm{O}$ record provides an alternative, extremely high-resolution correlation and dating tool for researchers working with Pliocene-Pleistocene marine sediments.

\section{CYCLOSTRATIGRAPHY OF THE MEDITERRANEAN}

In the Mediterranean region similar work was being carried out by Hilgen (1991a). In that basin, sedimentary cycles occur frequently and are widespread in the marine sequences of the Neogene Period. They include a wide variety of rock types such as marl-limestone alternations, sapropels, diatomites, and even turbidites and evaporites (e.g. Ryan, 1972; Vai and Ricci Lucchi, 1977; McKenzie et al., 1979; Meulenkamp et al., 1979; Hilgen, 1987; Rio et al., 1989; Postma et al., 1993; Weltje and de Boer, 1993). These sedimentary cycles, in particular the sapropel record of the upper Pleistocene, are also linked to astronomically in- duced variations in climate (e.g., Ryan, 1972; Cita et al., 1978; Vergnaud-Grazzini et al., 1977; Calvert, 1983; Rossignol-Strick, 1983; Thunell et al., 1984; Rohling and Gieskes, 1989).

In southern Italy, sapropel-bearing sequences are found in the upper Pliocenelower Pleistocene Narbone Formation (Fig. 2). As in upper Pleistocene piston cores, sapropels in the Narbone Formation are not distributed evenly in the stratigraphic record but occur in clusters on various scales: large-scale clusters commonly comprise several (two to three) small-scale clusters that in turn contain one to four individual sapropels. The Narbone Formation is underlain by the rhythmically bedded marls of the lower Pliocene Trubi Formation. The conspicuous rhythmic bedding in the Trubi consists mainly of quadripartite depositional sequences displaying a distinct gray-whitebeige-white color layering, with the gray and beige beds being less indurated and $\mathrm{CaCO}_{3}-$ poor. In addition to these small-scale color cycles, larger-scale cycles are easily distinguished by the regular recurrence of relatively thick, indurated and $\mathrm{CaCO}_{3}$-rich intervals.

Although it had been suggested that these bedding cycles were connected with the Earth's orbital cycles (Meulenkamp et al., 1979), the inferred astronomical forcing and its potential geochronological application had never been studied systematically. Two main factors contributed to this disregard: the lack of a sufficiently long and continuous rhythmically bedded sequence, and the lack of an accurate (first-order) time-stratigraphic framework. The first of these problems was solved by field-stratigraphic surveys in the Capo Rossello area and in Calabria, which identified a continuous composite sequence of the Trubi and the lowermost part of the Narbone Formation (Hilgen, 1987, 1990).

The second problem was resolved by a magnetostratigraphic study of the new Rossello composite section, which showed that the Trubi and lower part of the Narbone Formation range in age from the oldest reversed subchron of the Gilbert Chron to the oldest reversed subchron of the Matuyama Chron (Langereis and Hilgen, 1991). The upper part of the Narbone Formation as exposed in the Singa and Vrica sections (Calabria) ranges in age from the youngest normal subchron of the Gauss Chron to younger than the Olduvai Subchron (Tauxe et al., 1983; Zijderveld et al., 1991). 


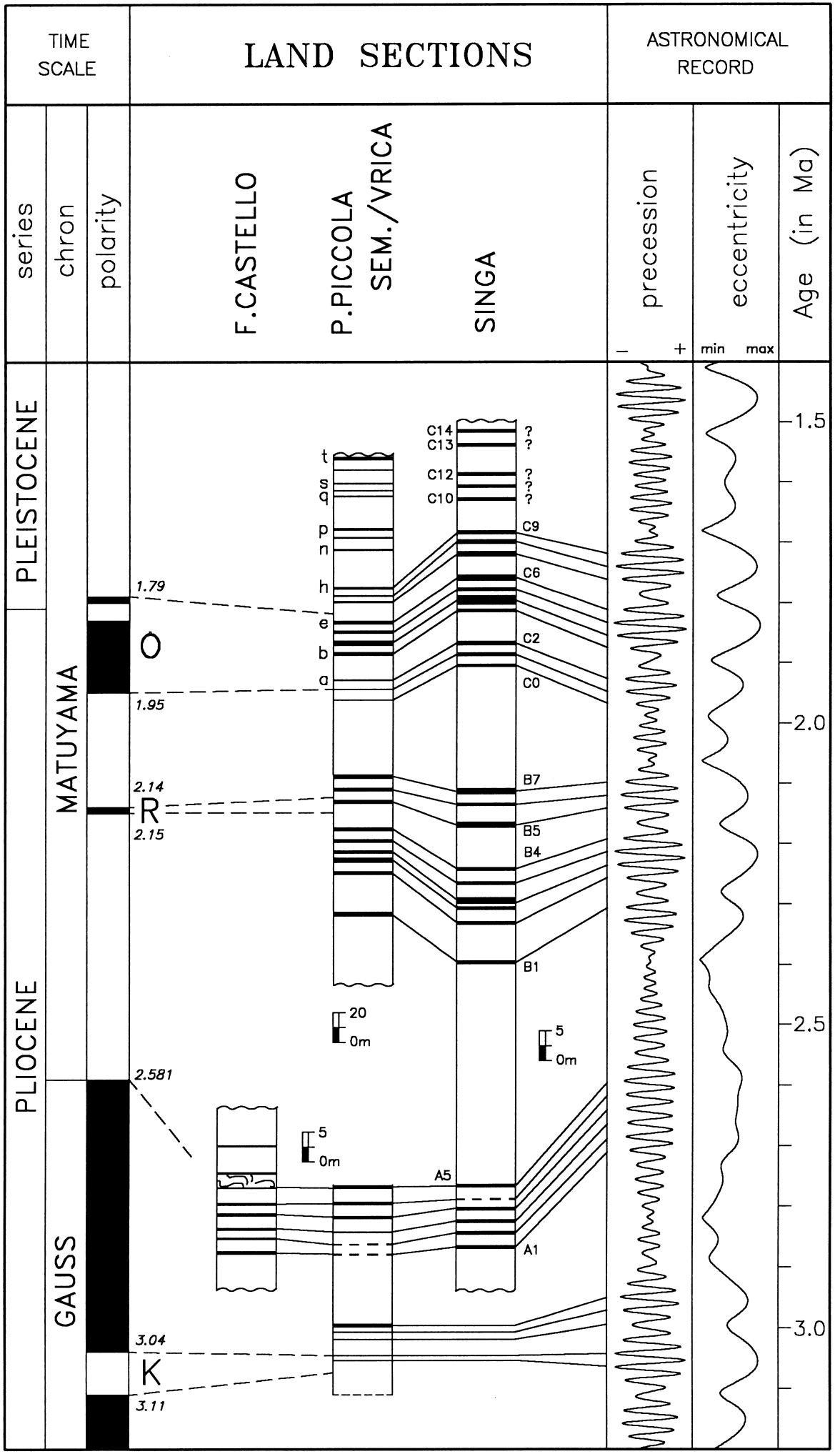

Figure 2. Astronomical calibration of sapropels in the Narbone Formation (modified after Hilgen, 1991a). Sapropel codifications after Selli et al. (1977) and Verhallen (1987) for the Vrica and Singa sections, respectively. Astronomical time series after solution BER90 (Berger and Loutre, 1991). Note that a detailed study of the Gauss/Matuyama boundary has led to a slight revision of the initial astronomical age for this reversal (Langereis et al., 1994), which is adopted here.
The continuous and magnetostratigraphically controlled composite sequence of cyclically bedded marine sediments of the Trubi and Narbone Formations served as a starting point for constructing an astronomically tuned time scale. The observation that periodicities of $\mathrm{CaCO}_{3}$ cycles in the Trubi differ consistently from periodicities of the astronomical cycles (Berger and Loutre, 1991) if the geomagnetic polarity time scale of Berggren et al. (1985a, 1985b) was used (Hilgen and Langereis, 1989) gave further impetus to this attempt.

The astronomically calibrated time scale was constructed in two steps. First, the upper Pliocene-lower Pleistocene sapropel sequences were correlated to the orbital time series. Phase relations between sapropel and astronomical cycles were established by tying the youngest sapropels of late Pleistocene age to the astronomical record. This procedure revealed that individual sapropels correlate with minima of the precession index and that small-scale and large-scale sapropel clusters correspond to eccentricity maxima at 100 and $400 \mathrm{ka}$, respectively. These phase relations were used to calibrate the older sapropels in our land sections to the astronomical record (Hilgen, 1991a; Hilgen et al., 1993; see also Fig. 2). Because these sapropels remain restricted to the upper Pliocene-lower Pleistocene, the $\mathrm{CaCO}_{3}$ cycles of the Trubi (lower Pliocene) were employed to extend the time scale back to the Miocene/Pliocene boundary (see Hilgen, 1991b, for discussion of methodology). Accepting the accuracy of the astronomical solution of Berger and Loutre (1991), this calibration of sedimentary cycles dates all sapropels and $\mathrm{CaCO}_{3}$ cycles with an accuracy of $\approx 1-2$ k.y., assuming a time lag of 3 k.y. between orbital forcing and maximum climate response (e.g., sapropel formation).

The presence of high-resolution magnetostratigraphic and biostratigraphic records in all sections meant that all bioevents and polarity reversals, from the top of the Olduvai Submagnetozone down to the bottom of the Thvera Submagnetozone, could be dated with a similar accuracy (of 5-10 k.y.; see Table 2). Astronomical ages were further obtained for the Pliocene/Pleistocene and Miocene/Pliocene boundaries. All ages were significantly older than ages given by earlier time scales based on radiometric dating; however, they were in essential agreement with the astronomically derived ages of SBP90. (Note that high-resolution studies of the polarity transitions in these sediments revealed a complication in establishing the 
TABLE 2. AGE ESTIMATES MADE SINCE 1979 FOR CHRON AND SUBCHRON BOUNDARIES BASED ON VARIOUS METHODOLOGIES

\begin{tabular}{|c|c|c|c|c|c|c|c|c|c|c|c|c|c|c|}
\hline \multicolumn{3}{|c|}{ Polarity chron and subchron ${ }^{\star}$} & \multicolumn{2}{|c|}{ Isotopic } & $\begin{array}{c}\text { Geomagnetic } \\
\text { BKV (3) }\end{array}$ & \multicolumn{2}{|c|}{ Astronomical } & \multicolumn{4}{|c|}{ Isotopic } & $\begin{array}{l}\text { Spline fit } \\
\text { C\&K (10) }\end{array}$ & $\begin{array}{l}\text { Isotopic } \\
\text { O\&I (11) }\end{array}$ & $\begin{array}{l}\text { Astroisomagnetic } \\
\text { SHCK (12) }\end{array}$ \\
\hline ตे & & & 0.73 & -0.72 & -0.73 & -0.78 & - & $-0.783-$ & $->0.75-$ & $-0.780-$ & $-0.75-$ & $-0.780-$ & $-0.78-$ & 0.78 \\
\hline \multirow{11}{*}{ 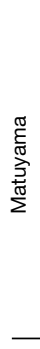 } & Jaramillo (N) & T & 0.90 & 0.89 & 0.91 & 0.99 & & & $>0.99$ & 0.915 & 0.992 & 0.984 & $>0.955$ & 0.99 \\
\hline & & B & 0.97 & 0.94 & 0.98 & 1.07 & & & & 1.010 & & 1.049 & $>1.00$ & 1.07 \\
\hline & Cobb Mtn (N) & $\mathrm{T}$ & 1.10 (mid) & & & & & & & & & 1.201 & 1.21 & 1.21 \\
\hline & & B & & & & 1.19 & & & & & & 1.212 & 1.24 & 1.24 \\
\hline & Olduvai (N) & $\mathrm{T}$ & 1.67 & 1.76 & 1.66 & 1.77 & 1.79 & & & 1.78 & & 1.757 & & 1.77 \\
\hline & & B & 1.87 & 1.91 & 1.88 & 1.95 & 1.95 & & $1.98-2.01$ & 1.96 & & 1.983 & $>1.96$ & 1.95 \\
\hline & Reunion II (N) & $\mathrm{T}$ & 2.01 & 2.07 & & & 2.14 & $2.11-2.13$ & & 2.11 & & & 2.11 & 2.14 \\
\hline & & B & 2.04 & & & & 2.15 & $2.11-2.15$ & & 2.15 & & & & 2.15 \\
\hline & Reunion I (N) & T & 2.12 & & & & & & & 2.19 & & 2.197 & & \\
\hline & & B & 2.14 & & & & & & & 2.27 & & 2.229 & $>2.18$ & \\
\hline & & & 2.48 & -2.47 & -2.47 & -2.60 & $-2.60-$ & - & - & -2.60 & & -2.600 & & 2.58 \\
\hline \multirow{5}{*}{ 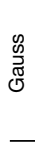 } & Kaena (R) & T & 2.92 & 2.91 & 2.92 & & 3.04 & & 3.04 & 3.02 & & 3.054 & & 3.04 \\
\hline & & B & 3.01 & 3.00 & 2.99 & & 3.11 & & 3.10 & 3.09 & & 3.127 & & 3.11 \\
\hline & Mammoth (R) & $\mathrm{T}$ & 3.05 & 3.07 & 3.08 & & 3.22 & & 3.21 & 3.21 & & 3.221 & & 3.22 \\
\hline & & B & 3.15 & 3.17 & 3.18 & & 3.33 & & 3.30 & 3.29 & & 3.325 & & 3.33 \\
\hline & & & 3.40 & -3.41 & -3.40 & - & $-3.58-$ & - & - & $-3.57-$ & & -3.553 & & 3.58 \\
\hline \multirow{9}{*}{$\frac{t}{0}$} & Cochiti (N) & T & 3.80 & 3.82 & 3.88 & & 4.18 & & & & & 4.033 & & 4.18 \\
\hline & & B & 3.90 & 3.92 & 3.97 & & 4.29 & & & & & 4.124 & & 4.29 \\
\hline & Nunivak (N) & $\mathrm{T}$ & 4.05 & 4.07 & 4.10 & & 4.48 & & & & & 4.265 & & 4.48 \\
\hline & & B & 4.20 & 4.25 & 4.24 & & 4.62 & & & & & 4.432 & & 4.62 \\
\hline & Sidufjall (N) & $\mathrm{T}$ & 4.32 & 4.44 & 4.40 & & 4.80 & & & & & 4.611 & & 4.80 \\
\hline & & B & 4.47 & 4.57 & 4.47 & & 4.89 & & & & & 4.694 & & 4.89 \\
\hline & Thvera $(\mathrm{N})$ & T & 4.85 & 4.72 & 4.57 & & 4.98 & & & & & 4.812 & & 4.98 \\
\hline & & B & 5.00 & 4.94 & 4.77 & & 5.23 & & & & & 5.046 & & 5.23 \\
\hline & & & & -5.44 & -5.35 & - & & - & - & - & & & - & 5.89 \\
\hline & & & & & & & & & & & & & & \\
\hline
\end{tabular}

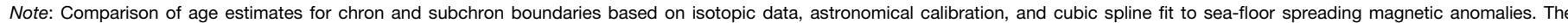

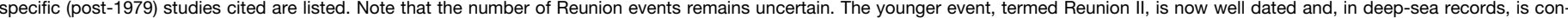

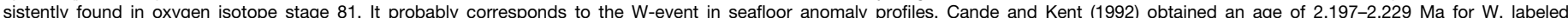

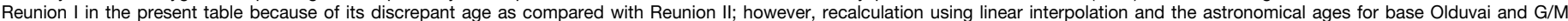
boundary yields an age of 2.169-2.202 Ma, making it virtually indistinguishable from the Reunion II. At present no consistent data set exists for an older Reunion event.

${ }^{\star} \mathrm{N}=$ normal, $\mathrm{R}=$ reversed, $\mathrm{T}=$ top, $\mathrm{B}=$ bottom.

$\mathrm{N}=$ normal, $\mathrm{R}=$ reversed, $\mathrm{T}=$ top, $\mathrm{B}=$ bottom.

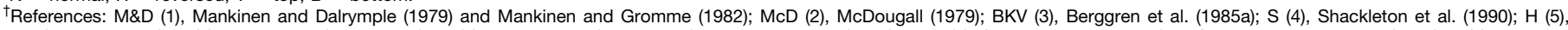

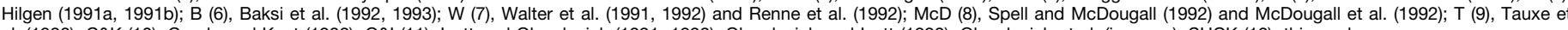
al. (1992); C\&K (10), Cande and Kent (1992), O\&I (11), Izett and Obradovich (1991, 1992), Obradovich and Izett (1992), Obradovich et al. (in press); SHCK (12), this work.

exact position, and thus age, of reversal boundaries [Linssen, 1988; Van Hoof and Langereis, 1991, 1992; Van Hoof et al., 1993; Langereis et al., 1994]. It appears that the polarity of the Earth's magnetic field [e.g., following a reversal] still can be imprinted at a considerable depth, 1-1.5 m below the sediment-water interface. This artifact, presumably related to recurrent and cyclic redox conditions [early diagenesis], implies that astronomical ages for polarity reversals in the Trubi may be too old by $5-10$ k.y. This would slightly reduce but still not explain the age discrepancies between astronomically calibrated and conventional [K/Ar] datings of the polarity reversals.)

\section{Isotopic Radiochronology}

The GPTS of Mankinen and Dalrymple (1979) represents the latest major synthesis of isotopic data related to rocks having specific polarity signatures. Subsequent geomagnetic polarity time scales (Berggren et al., 1985a, 1985b; Harland et al., 1982, 1990) have used the Mankinen and Dalrymple GPTS as an integral part of their late Cenozoic studies. Johnson (1982) was the first to suggest that the radiometrically determined age of the Brunhes-Matuyama boundary was incorrect. By correlating major glacial extremes $\left(\delta^{18} \mathrm{O}\right.$ minima) to major insolation minima, he arrived at an estimated age of $0.79 \mathrm{Ma}$, in contrast to the age of 0.73 Ma reported for this boundary (Mankinen and Dalrymple, 1979). This article was largely ignored by the geochronological community; however, Shackleton et al. (1990) again raised the issue when they proposed a new astronomical calibration of the early Pleistocene time scale. Not only did this time scale challenge the age of the
Brunhes/Matuyama boundary (0.78 versus $0.73 \mathrm{Ma}$ ) but, in combination with the study of Hilgen and Langeris (1989), questioned the correctness of all ages for chron and subchron boundaries during the past 5.0 m.y.

At the time, it was difficult for the geochronological community to perceive of any mechanism that could consistently bias the isotopically derived ages by $5 \%-7 \%$ over a period of $>5$ m.y. (Shackleton et al., 1990; Hilgen, 1991a and 1991b). Explanations for the consistent age discrepancies ranged from imprecision of individual age determinations, to diffusive loss of radiogenic argon, to inadequately known decay constants. The last was readily dismissed, because the current estimate of the error for the decay constant of ${ }^{40} \mathrm{~K}$ is $<0.5 \%$ (Gale, 1982). As $>90 \%$ of the data utilized by Mankinen and Dalrymple are from whole-rock basalts and andesites, a more likely possibility was sys- 
tematic loss of argon from the glassy matrix (the site of the bulk of the potassium) or a loss due to unrecognizable alteration. In this case, all of the data would have to be questioned despite great efforts made to provide criteria by which suitable whole-rock samples could be selected (Dalrymple and Lanphere, 1969; McDougall, 1971). Likewise, diffusive loss of argon from sanidine as well as biotite and plagioclase minerals also seemed an untenable explanation as diffusion studies on sanidine yielded high activation energies (Fetchig and Kalbitzer, 1966; Musset, 1969). It was McDowell (1983) who first suggested, but did not prove conclusively, that it was difficult to totally degas sanidine, leading to an underestimated age. Deino et al. (1989) later demonstrated that this resulted in young ages for nine sanidine samples employed by Mankinen and Dalrymple (1979). When ${ }^{40} \mathrm{Ar}-{ }^{39} \mathrm{Ar}$ ages were compared to conventional $\mathrm{K}-\mathrm{Ar}$ ages on sanidine, the ${ }^{40} \mathrm{Ar}-{ }^{39} \mathrm{Ar}$ ages were invariably older, some times by as much as $20 \%$, although 5\%-10\% would be more in keeping with the experience of one of us (Obradovich). Further, as the constraining ages on the Brunhes/Matuyama boundary and the Jaramillo Subchron were based on sanidine, this implied that the time scale of Mankinen and Dalrymple was indeed biased toward young ages.

The first ${ }^{40} \mathrm{Ar}-{ }^{39} \mathrm{Ar}$ studies (Izett and Obradovich, 1991) on sanidine from the normally magnetized Bishop Tuff (middle Pleistocene) increased the age determination from $0.74 \mathrm{Ma}$ (Izett et al., 1988) to $0.77-0.78$ Ma (the age determination depends on the choice of age for the irradiation monitor). At the same time, Baksi et al. (1992) demonstrated an ${ }^{40} \mathrm{Ar}-{ }^{39} \mathrm{Ar}$ plateau age of 0.78 Ma in whole-rock basalt samples with transitional polarity from Maui, Hawaii. These ${ }^{40} \mathrm{Ar}-{ }^{39} \mathrm{Ar}$ age estimates for the Brunhes/ Matuyama boundary were in much closer agreement with those proposed by Johnson (1982) and Shackleton et al. (1990).

These initial results spurred a flurry of activity in which the Jaramillo, Cobb Mountain, Olduvai, Reunion, Kaena, and Mammoth Subchrons and the Matuyama-Gauss and Gauss-Gilbert Chron boundaries were investigated. For sake of brevity these recent studies are summarized in Table 2 along with the pertinent citations. Also included for comparison are the GPTS of Berggren et al. (1985a, 1985b), the relevant portion of the magnetic anomaly time scale of Cande and Kent (1992), and the astronomically based chronology adopted in this paper (col- umn 12 in Table 2). What is evident from this compilation is that all reversal boundaries for the past 5 m.y. given in Mankinen and Dalrymple (1979) and McDougall (1979) are too young and that the new ${ }^{40} \mathrm{Ar}-$ ${ }^{39} \mathrm{Ar}$ ages are in general agreement with the astronomically calibrated scale.

This brings into question the overall accuracy of conventional K-Ar ages on wholerock basalt and andesite samples. Despite earlier statements by one of us (Obradovich), loss of radiogenic ${ }^{40} \mathrm{Ar}$ has taken place in these whole-rock samples either as a result of diffusion or alteration. Until ${ }^{40} \mathrm{Ar}$ ${ }^{39} \mathrm{Ar}$ incremental heating studies are carried out on most of the whole-rock samples making up the database of Mankinen and Dalrymple, however, it will be difficult to decide the intrinsic value of any one data point, particularly in those intervals having a large number of reversal events. Finally, some differences between the new isotopically and astronomically calibrated time scales cannot be explained by a bias resulting from calibration errors in the isotopic data. For instance, the ages for the Cobb Mountain Subchron and the base of the Olduvai deviate far more than would be expected given the resolution attributed to the astronomical approach ( $\approx 5$ k.y.).

\section{A New Geomagnetic Polarity Time Scale}

Age estimates of geomagnetic polarity reversals during Pliocene and Pleistocene time have been based traditionally on paired $\mathrm{K}$-Ar age and magnetization polarity determinations on lavas distributed more or less at random in time and space. The initial impetus for this approach was to test the hypothesis of self-reversal as an explanation for reversed magnetizations in rocks, a localized phenomenon that would not be expected to produce a globally consistent temporal distribution of magnetic polarities (e.g., Cox et al., 1963, 1964). This methodology for the construction of a GPTS is limited by the nonuniform age distribution of the K-Ar and polarity data as well as by the accuracy and precision of the K-Ar radiometric ages themselves. To minimize these problems, Cox and Dalrymple (1967) introduced the chronogram method in which the most likely age of a reversal is that which minimizes the apparent inconsistency in a population of dated lavas of known polarity.

In the most recent comprehensive analysis of the K-Ar/polarity data set for the past 5 m.y., Mankinen and Dalrymple (1979) used the chronogram method to provide age estimates for the reversal boundaries between the Brunhes/Matuyama (0.73 Ma), Matuyama/Gauss (2.47 Ma), and Gauss/Gilbert (3.40 Ma) Chrons. These estimates have been used widely for Pliocene-Pleistocene chronostratigraphy, and the age of the Gauss/Gilbert boundary has been, until very recently, a critical calibration point for virtually all geomagnetic polarity time scales based on marine magnetic anomalies since the classic study of Heirtzler et al. (1968).

In contrast to lavas on land, continuous high-resolution records of geomagnetic polarity can be obtained from the magnetostratigraphy of deep-sea sediments and from sea-floor spreading magnetic anomalies. Magnetostratigraphy allows direct correlation of biostratigraphy with the reversal sequence necessary for the construction of integrated geologic time scales. The validity of the marine magnetic anomaly record is established by the high redundancy of data available from the various ridge systems in the global ocean. Indeed, the geomagnetic polarity sequence inferred from sea-floor spreading magnetic anomalies has effectively become the standard reference for geomagnetic reversals extending back to the Jurassic Period. However, the high-resolution geomagnetic reversal sequence obtained by these methods must be calibrated in time using some independent source of age information.

In comparison with the frequency of geomagnetic reversals, there have been relatively few reliable, analytically precise, and stratigraphically well-controlled radiometric dates available to establish a chronology. Oceanic basalts, the source of the magnetic anomalies, are notoriously difficult to date radiometrically, and datable horizons in magnetostratigraphic sections have been reported infrequently-hence the need for interpolation between selected calibration datums that have been correlated to the characteristic reversal pattern. For example, Cande and Kent (1992) used nine calibration tie points plus the origin for fitting a cubic spline to a revised magnetic anomaly sequence in the South Atlantic, to derive a GPTS (CK92) consisting of 181 reversals during the past 83 m.y.. The calibration points that served to constrain the PliocenePleistocene portion of CK92 are the zeroage ridge axis, $0.78 \mathrm{Ma}$ for the older end of the central anomaly (Chron C1n; Brunhes/ Matuyama boundary), $2.60 \mathrm{Ma}$ for the younger end of anomaly 2A (Chron C2An; Matuyama/Gauss boundary), and $14.8 \mathrm{Ma}$ 


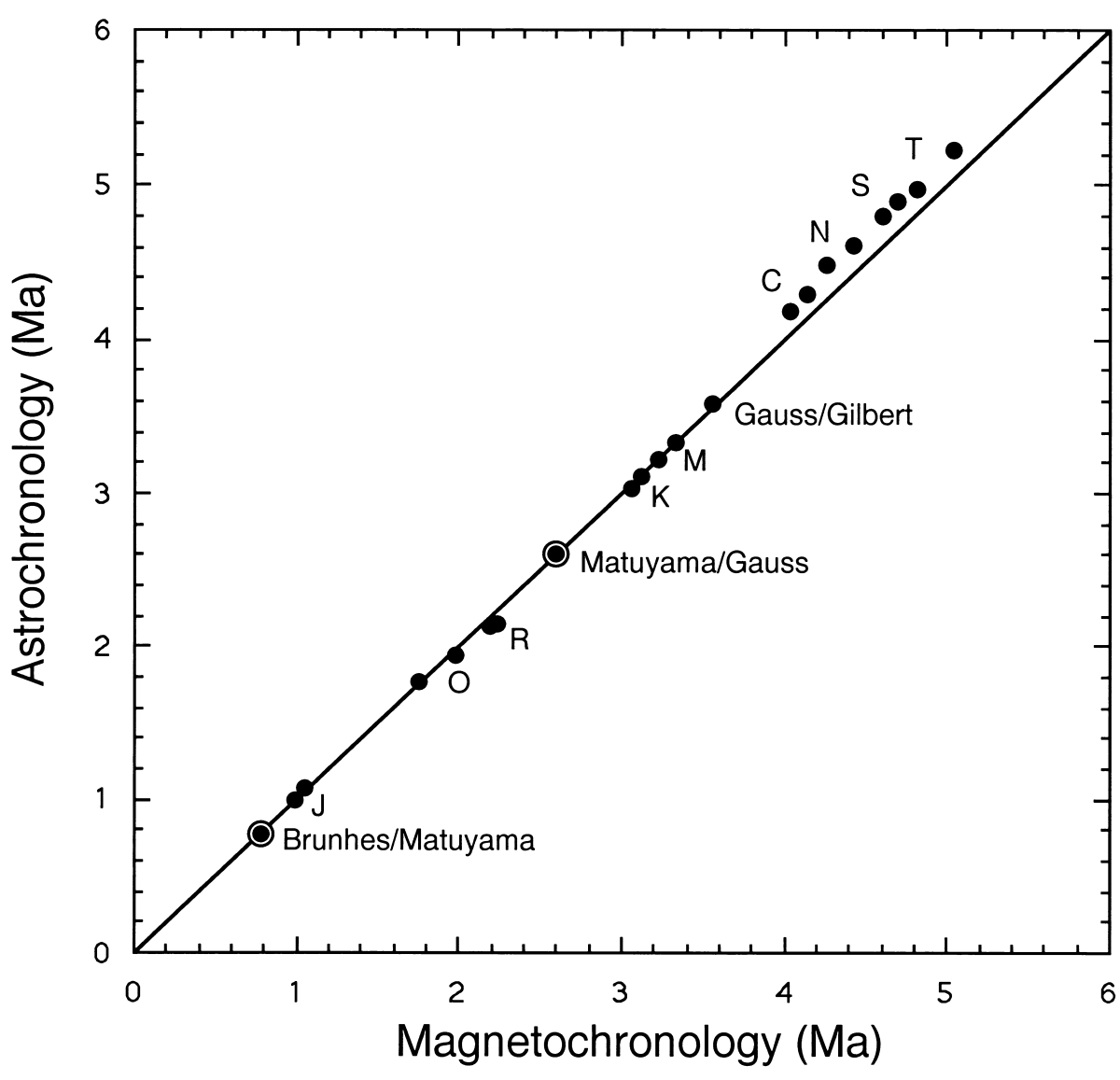

Figure 3. Ages of geomagnetic reversals determined from astrochronology (Shackleton et al., 1990; Hilgen, 1991b) compared to magnetochronology (Cande and Kent, 1992). Doubled circles are calibration points from astrochronology that were used in the magnetochronology of CK92. Chron boundaries indicated; subchron boundaries are J, Jaramillo; O, Olduvai; R, Reunion; M, Mammoth; K, Kaena; C, Cochiti; N, Nunivak; S, Sidufjall; and T, Thvera.

for the younger end of anomaly 5B (Chron C5Bn).

As described earlier, a new approach to geochronology has been to date high-resolution climate records by assuming that their characteristic variability is related to wellknown variations in Earth's orbital parameters. Unlike discrete radiometric dates, which require interpolation using sedimentation or spreading rates, the astrochronologic method can effectively provide a continuum of independent age control; the precision is effectively a function of the shortest Milankovitch orbital variation $(\approx 20$ k.y. precession cycle), and the accuracy depends on how reliably one can calculate orbital parameters back in time. As described above, Shackleton et al. (1990) developed an astrochronologic time scale to the level of the Gauss/Matuyama boundary. Hilgen (1991b) extended the astrochronology through the Thvera (C3n.4n) Subchron in the early part of the Gilbert Epoch (Gilbert Chron herein). Over the interval of overlap, there is excellent agreement in the ages derived from these independent sets of data, ages which have recently been confirmed by high-precision ${ }^{40} \mathrm{Ar}-{ }^{39} \mathrm{Ar}$ dating (e.g., Baksi et al., 1992; Tauxe et al., 1992; Walter et al., 1991; Renne et al., 1993); however, ${ }^{40} \mathrm{Ar}$ ${ }^{39} \mathrm{Ar}$ dates generally provide younger age estimates than conventional $\mathrm{K}-\mathrm{Ar}$ dates for the earlier Cenozoic (e.g., Berggren et al., 1992; Cande and Kent, 1992), opposite of the trend in the Pliocene and Pleistocene.

A comparison of the astrochronology of Shackleton et al. (1990) and Hilgen (1991b) with the GPTS of Cande and Kent (1992) shows good agreement back to the base of the Gauss (Fig. 3). This is, of course, not unexpected because the calibration points at the Brunhes/Matuyama (0.78 Ma) and
Matuyama/Gauss (2.60 Ma) boundaries in CK92 were based on these astrochronologic estimates. A significant difference, however, occurs in the Gilbert Chron, where astrochronology suggests ages for the subdivisions of Chron C3n (Cochiti, Nunivak, Sidufjall, and Thvera Subchrons) that are systematically 150-180 k.y. older than the ages inferred from cubic spline interpolation in CK92 (Fig. 3). The problem evidently lies in the interval between the base of the Gauss (Chron C2An), for which there is good agreement (within 30 k.y.) between the chronologies, and the top of the Cochiti (C3n.1n) Subchron, where the discrepancy suddenly becomes 147 k.y. It is now apparent that the magnetic anomaly sequence for this interval used by Cande and Kent (1992) is the likely source of the problem. This was demonstrated by Wilson (1993), who showed that the astrochronology gives a more consistent spreading history when applied to a set of revised spacings of anomalies on the Cocos-Nazca and other Pacific spreading ridges.

The success of the continuous chronology provided by the astronomical time scale means that it is not necessary to interpolate between a few discrete dated levels to construct a geomagnetic polarity time scale for this interval. Instead, the ages of reversals in the interval where astrochronology has been developed and confirmed simply become equivalent to the astrochronological values, thereby avoiding the promulgation of separate time scales. Astrochronological estimates for geomagnetic reversals back to the base of the Thvera Subchron are presented in Table 2 (Shackleton et al.; 1990 Hilgen, 1991b). Older than the Thvera Subchron, interpolation using marine magnetic anomalies is still necessary (Cande and Kent, 1995). This procedure gives a predicted age of 5.894 Ma for the base of the Gilbert (Chron C3r/C3An boundary). This interpolated age compares favorably with a tentative astronomical estimate of $5.882 \mathrm{Ma}$ for this level based on results from ODP Leg 138 Site 852 (Shackleton et al., in press).

\section{A NEW GLOBAL HIGH-RESOLUTION BIOSTRATIGRAPHY}

In this section we delineate the main biostratigraphic datum events of the late Neogene succession in a series of tables. All datum events have been recalibrated to the new GPTS of Cande and Kent (1995), which is identical to the astronomical time scale of Shackleton et al. (1990) and Hilgen (1991a, 
LATE NEOGENE CHRONOLOGY

1991b). The ages of these datums differ slightly, but significantly in some instances, from the chronology in Berggren et al. (1985a and 1985b).

In Tables 3 and 4 age calibrations of Pliocene and Pleistocene calcareous nannoplankton global datum events are reported with their position versus the GPTS and stable isotope stratigraphy (references from Thierstein et al., 1977; Backman and Shackleton, 1983; Haq and Takayama, 1984; Berggren et al., 1985a; Backman and Pestiaux, 1987; Rio et al., 1990; Raffi et al., in press). These events are evolutionary appearances (first appearance datums, or FADs) and extinctions (last appearance datums, or LADs), and events caused by environmental changes such as fluctuations in presence and abundance of taxa (increase, acme, dominance, absence) and migrations (first occurrences, or FOs, and last occurrences, or LOs) in different biogeographic provinces. These events are reliable (reproducible in different sequences and among different authors), distinct, and easily recognized (appearance datums of taxa with unambiguous taxonomic definition). Bioevents excluded from this list are those with regional value (recorded and calibrated in restricted areas), events calibrated with no spatial accuracy (i.e., in a single locality), or events with uncertain biochronologic evaluations. For some of the taxa listed in Tables 3 and 4 a nonisochronous appearance datum (FAD or LAD) has been proved. Examples are: (1) the Ceratolithus rugosus FAD, which in oceanic areas occurs within the Thvera Subchron (Haq and Takayama, 1984), while in the Mediterranean is placed at the top of the Nunivak Subchron (Rio et al., 1990); (2) the Helicosphaera sellii LAD, diachronous with latitude in open-ocean sediments (Backman and Shackleton, 1983); (3) reentry of medium-size Gepyrocapsa spp., time transgressive between the low-latitude sections and the middle- to high-latitude sections (Raffi et al., 1993); and (4) the increase in abundance of $E$. huxleyi (reversal of dominance between $G$. carribeanica and E. huxleyi), time transgressive between tropical subtropical waters and transitional waters (Thierstein et al., 1977).

The numerous nannofossil datums result from rapid evolutionary turnover during the climatically unstable Pliocene and Pleistocene and provide a detailed biostratigraphic framework for this time interval. This set of calibrated bioevents, transformed to biochronologic datums, provides a high degree of stratigraphic resolution in the marine
TABLE 3. BIOCHRONOLOGY OF PLIOCENE CALCAREOUS NANNOFOSSILS

\begin{tabular}{|c|c|c|}
\hline Datum event & Magnetic polarity & $\begin{array}{l}\text { Age } \\
(\mathrm{Ma})^{\star}\end{array}$ \\
\hline Triquetrorhabdulus rugosus $\mathrm{LAD}^{\dagger}$ & In the uppermost part of the lowest reversed interval of Gilbert & $5.34(a, b)$ \\
\hline Ceratolithus acutus $\mathrm{FAD}^{\S}$ & In the uppermost part of the lowest reversed interval of Gilbert & $5.34(a, b)$ \\
\hline Ceratolithus rugosus FAD & $\begin{array}{l}\text { Within Thvera (oceanic areas) } \\
\text { Near top of Nunivak (Mediterranean) }\end{array}$ & $\begin{array}{l}5.0-5.23(c) \\
4.5(d)\end{array}$ \\
\hline Amaurolithus primus LAD & $\begin{array}{l}\text { Near top of Sidufjall (oceanic areas) } \\
\text { Within Nunivak (Mediterranean) }\end{array}$ & $\begin{array}{l}4.8(a) \\
4.55(d)\end{array}$ \\
\hline Discoaster asymmetricus $\mathrm{FCO}^{\#}$ & $\begin{array}{l}\text { Near top of Cochiti (oceanic areas) } \\
\text { In upper Gilbert (Mediterranean) }\end{array}$ & $\begin{array}{l}4.2(d) \\
4.15(c)\end{array}$ \\
\hline $\begin{array}{l}\text { Reticulofenestra pseudoumbilicus } \\
\text { LAD }\end{array}$ & In the uppermost part of the upper reversed interval of Gilbert & $\begin{array}{l}3.75(e) \\
3.65-3.7^{\star \star}(d)\end{array}$ \\
\hline Sphenolithus spp. LAD & Near base of Gauss & $\begin{array}{l}3.6(f) \\
3.55-3.6^{\star \star}(d)\end{array}$ \\
\hline Discoaster tamalis LAD & Near top of Gauss & $\begin{array}{l}2.78(g) \\
2.73^{\star \star}(d)\end{array}$ \\
\hline Discoaster surculus LAD & Close to the Matuyama/Gauss boundary & $\begin{array}{l}2.55-2.59(g) \\
2.55^{\star \star}(d)\end{array}$ \\
\hline Discoaster pentaradiatus LAD & Close to the Matuyama/Gauss boundary & $\begin{array}{l}2.46-2.56(g) \\
2.55^{\star \star}(d)\end{array}$ \\
\hline Discoaster triradiatus & Onset acme in the early Matuyama & $\begin{array}{l}2.18(g) \\
2.25^{\star \star}(d)\end{array}$ \\
\hline $\begin{array}{c}\text { Discoaster brouweri LAD plus } \\
\text { Discoaster triradiatus LAD }\end{array}$ & In the lowermost Olduvai (oceanic areas and Mediterranean) & $1.95(\mathrm{~d}, \mathrm{~g})$ \\
\hline \multicolumn{3}{|c|}{$\begin{array}{l}\text { Note: The position of the bioevents versus the magnetostratigraphy is indicated. Magnetobiochronology } \\
\text { calibrated to the time scale shown in Table 2, column } 12 \text { (this work). } \\
\text { *References: a, Berggren et al. (1985a); b, Raffi and Flores (in press); c, Haq and Takayama (1984); d, Rio et al. } \\
\text { (1990); e, Mazzei et al. (1979); f, Backman and Shackleton (1983); g, Backman and Pestiaux (1987). } \\
{ }^{+} \text {LAD = last appearance datum. } \\
\text { \$FAD = first appearance datum. } \\
\text { "FCO = first common occurrence. }\end{array}$} \\
\hline
\end{tabular}

TABLE 4. BIOCHRONOLOGY OF PLEISTOCENE CALCAREOUS NANNOFOSSILS

\begin{tabular}{|c|c|c|}
\hline Datum event & $\begin{array}{l}\text { Isotope stratigraphy } \\
\text { (magnetic polarity) }^{\star}\end{array}$ & $\begin{array}{l}\text { Age } \\
(\mathrm{Ma})^{*}\end{array}$ \\
\hline $\begin{array}{l}\text { Medium Gephyrocapsa spp. FAD }{ }^{\dagger} \\
\text { (bmG event) }\end{array}$ & $\begin{array}{l}\text { Transition stages } 59 / 60(e) \\
\text { (above top of Olduvai) }\end{array}$ & $1.67-1.70(a)$ \\
\hline Calcidiscus macintyrei $\mathrm{LAD}^{\S}$ & Upper stages 55 (e) & $1.59(c)$ \\
\hline $\begin{array}{l}\text { Large Gephyrocapsa spp. FAD } \\
\quad \text { (blG event) }\end{array}$ & Upper stage 48 (e) & $1.46-1.48(a)$ \\
\hline Helicosphaera sellii LAD & $\begin{array}{l}\text { Upper stage } 49 \\
\text { Stage } 37\end{array}$ & $\begin{array}{l}\text { (equatorial zone)1.47 (c) } \\
\text { (mid-latitudes) } 1.22 \text { (b) }\end{array}$ \\
\hline $\begin{array}{l}\text { Large Gephyrocapsa spp. LAD (tIG event) } \\
\text { Small Gephyrocapsa spp. beginning dominance }\end{array}$ & Stage 37 (e) & $1.22-1.24(a, b)$ \\
\hline $\begin{array}{l}\text { Medium Gephyrocapsa spp. reentrance } \\
\text { (reemG event) }\end{array}$ & Stage 29 (within Jaramillo) & $1.03(a)$ \\
\hline $\begin{array}{l}\text { Small Gephyrocapsa spp. end dominance } \\
\text { (=S2 event) }\end{array}$ & $\begin{array}{l}\text { Stage } 25 \text { (above Jaramillo in } \\
\text { Atlantic and Mediterranean) }\end{array}$ & $0.96(b)$ \\
\hline Pseudoemiliania lacunosa LAD & Stage 12 & $0.46(b, d)$ \\
\hline Emiliania huxleyi FAD & Stage 8 & $0.26(b, d)$ \\
\hline G. caribbeanica-E. huxleyi & Stage 4 (in transition waters) & 0.075 \\
\hline $\begin{array}{l}\text { Reversal of dominance } \\
\text { (=Emiliania huxleyi increase) }\end{array}$ & $\begin{array}{l}\text { Stages } 5 a-5 b \text { (in tropical- } \\
\text { subtropical waters) }\end{array}$ & $0.09(b, d)$ \\
\hline \multicolumn{3}{|c|}{$\begin{array}{l}\text { Note: The position of the bioevents versus the oxygen isotope stratigraphy and magnetostratigraphy is } \\
\text { indicated. Magnetobiochronology calibrated to the time scale shown in Table 2, column } 12 \text { (this work). } \\
\text { *References: a, Rio et al. (in press); b, Rio et al. (1990); c, Backman and Shackleton (1983); d, Thierstein } \\
\text { et al. (1977); e, Raffi et al. (1993). } \\
{ }^{\dagger} F A D=\text { first appearance datum. } \\
\S \text { LAD = last appearance datum. }\end{array}$} \\
\hline
\end{tabular}


record $(\approx 0.3$ m.y. in the Pliocene and 0.2 m.y. in the Pleistocene). Some of the Pliocene bioevents of Table 3 have been recognized in the Mediterranean only (Rio et al., 1990) and are included because the standard Pliocene-Pleistocene chronostratigraphic (stage) units are defined in this region. These datums, together with planktonic foraminifera datums, provide an integrated biochronologic framework allowing reevaluation of the biostratigraphy and age of stratotype sections in the Pliocene and Pleistocene Series (Driever, 1988; Rio et al., 1991, in press).

Within this biochronologic framework, calcareous nannofossils represent the basic tool for long-distance correlations. Many of the nannofossil events are reasonably isochronous within widely separated areas, including the Mediterranean. They occur in the same isotope stage, within the same short magnetozone, or have the same relative spacing with respect to magnetozones. In particular, all but one of the Pleistocene nannofossil events appear isochronous between the Mediterranean and low- and middle-latitude oceanic areas (assuming 50 k.y. as a limit of isochrony; Raffi et al., 1993).

The biochronology of planktonic foraminiferal taxa used for biostratigraphic subdivision and correlation in the Pliocene and Pleistocene are listed in Tables 5 and 6, respectively. We note datum events that are restricted to the Mediterranean. Data tabulated in Berggren et al. (1985a) and believed to be still valid are cited from that source. Data developed since then come from various sources such as Dowsett (1988) for global occurrences, Weaver and Clement (1987) and Raymo et al. (1989) for the North Atlantic, Joyce et al. (1990) for the Gulf of Mexico, Srinivasan and Sinha (1993) and Chaproniere et al. (1994) for the IndoPacific, and Rio et al. (1990), Langereis and Hilgen (1991), and Zijderveld et al. (1991) for the Mediterranean. Finally, a PliocenePleistocene (sub)tropical planktonic foraminiferal biostratigraphic zonation and magnetobiochronology, based on this and a related study (Berggren et al., 1995), is presented (Figs. 4 and 5). The standard calcareous nannofossil zonal schemes are calibrated to this chronology, also.

\section{Pliocene-Pleistocene Chronostratigraphic Framework}

Geochronologic history, no matter how plausible and internally self-consistent, is still subject to stratigraphic cross examina-
TABLE 5. BIOCHRONOLOGY OF PLIOCENE PLANKTONIC FORAMINIFERA

\begin{tabular}{|c|c|c|}
\hline Datum event & Magnetic polarity & $\begin{array}{c}\text { Age } \\
(\mathrm{Ma})^{\star}\end{array}$ \\
\hline Globorotalia margaritae $\mathrm{FAD}^{\dagger}$ & $\begin{array}{l}\text { Mid-C3An.2n } \\
\text { Mid-C3An.2n (Mediterranean) }\end{array}$ & $\begin{array}{l}6.4(\mathrm{a}-\mathrm{c}) \\
5.32(\mathrm{~d}, \mathrm{e})\end{array}$ \\
\hline Globorotalia tumida FAD & Early Gilbert reversed & $5.60(a, f, g)$ \\
\hline Globorotalia sphericomiozea FAD & Early Gilbert reversed & $5.60(f, g)$ \\
\hline Globorotalia pliozea FAD & Early Gilbert reversed & $5.60(f)$ \\
\hline Globoquadrina dehiscens $\mathrm{LAD}^{\S}$ & Early Gilbert reversed & $5.80(a)$ \\
\hline Sphaeroidinella dehiscens s.I. FAD & Early Gilbert reversed & $5.20(a, f)$ \\
\hline Top Sphaeroidinellopsis spp." & Basal Thvera Subchron (Mediterranean) & $5.20(d, e, i)$ \\
\hline Globorotalia margaritae $\mathrm{FCO}^{\star *}$ & Mid-Thvera (Mediterranean) & $5.07(d, e)$ \\
\hline Globigerinoides seiglei LAD & Just above Sidufjall Subchron & $4.70(a)$ \\
\hline Globorotalia puncticulata FAD & $\begin{array}{l}\text { Nunivak Subchron } \\
\text { Nunivak (Mediterranean) }\end{array}$ & $\begin{array}{l}4.50 \text { (b) } \\
4.50 \text { (d, e, h, i, j) }\end{array}$ \\
\hline Globorotalia crassaformis FAD & $\begin{array}{l}\text { Nunivak Subchron } \\
\text { Gilbert/Gauss boundary (Mediterranean) }\end{array}$ & $\begin{array}{l}4.5(a, c) \\
3.58(d, e)\end{array}$ \\
\hline Pulleniatina spectabilis LAD & Top Cochiti Subchron & $4.20(a)$ \\
\hline Globoturborotalita nepenthes LAD & Top Cochiti Subchron & $4.20(a)$ \\
\hline Globorotalia margaritae $\mathrm{LCO}^{\dagger \dagger}$ & Just above Cochiti Subchron (Mediterranean) & $3.96(d, e)$ \\
\hline Pulleniatina ${ }^{\S \S}$ & Just above Cochiti Subchron & $3.95(a)$ \\
\hline Pulleniatina primalis LAD & Late Gilbert reversed & $3.65(a)$ \\
\hline Globorotalia margaritae LAD & $\begin{array}{l}\text { Gauss/Gilbert boundary } \\
\text { Late Gilbert (Mediterranean) }\end{array}$ & $\begin{array}{l}3.58(a, f) \\
3.79(d, e, i, j)\end{array}$ \\
\hline Globorotalia miocenica FAD & C2An.3n (Atlantic Ocean) & 3.55 (a) \\
\hline $\begin{array}{l}\text { Globorotalia puncticulata (temporary } \\
\text { disappearance) }\end{array}$ & Basal Gauss (Mediterranean) & $3.55(d, e)$ \\
\hline Globorotalia pertenuls FAD & C2An.3n & $3.45(a)$ \\
\hline Pulleniatina (disappearance) & C2An.3n (Atlantic) & $3.45(a)$ \\
\hline $\begin{array}{l}\text { Globorotalia crassaformis } \\
\text { (reappearance) }\end{array}$ & Below Mammoth (Mediterranean) & $3.35(d, e)$ \\
\hline Globorotalia tosaensis FAD & Just below Mammoth & $3.35(a)$ \\
\hline Globigerinoides fistulosus FAD & C2An.2r (base Mammoth) & $3.33(a)$ \\
\hline $\begin{array}{l}\text { Globorotalia puncticulata } \\
\text { (reappearance) }\end{array}$ & Mammoth (C2An.2r) (Mediterranean) & $3.31(d, e)$ \\
\hline Globorotalia sp. cf. G. crassula LAD & Mammoth (C2An.2r) (North Atlantic) & $3.30(b)$ \\
\hline Globorotalia crassaformis ${ }^{\S \S}$ & Mid-Mammoth (Mediterranean) & $3.26(d, e)$ \\
\hline Globorotalia inflata FAD & $\begin{array}{l}\text { Early Matuyama (Mediterranean) } \\
\text { Same (North Atlantic) }\end{array}$ & $\begin{array}{l}2.09(i, j, k) \\
2.09(b)\end{array}$ \\
\hline Sphaeroidinella dehiscens s.s. FAD & $\begin{array}{l}\text { Top Mammoth C2r.2r } \\
\text { (Mediterranean) }\end{array}$ & $\begin{array}{l}3.25(a) \\
2.19(k)\end{array}$ \\
\hline Sphaeroidinellopsis seminulina LAD & $\begin{array}{l}\text { Base Kaena } \\
\text { Just above Mammoth (Mediterranean) }\end{array}$ & $\begin{array}{l}3.12(b) \\
3.21(d, e, h, i)\end{array}$ \\
\hline Globorotalia multicamerata LAD & C2An.1r (Kaena) & $3.09(a)$ \\
\hline Dentoglobigerina altispira LAD & $\begin{array}{l}\text { C2An.1r (Kaena) } \\
\text { C2An.2n (late Mammoth, early Kaena) } \\
\text { (Mediterranean) }\end{array}$ & $\begin{array}{l}3.09(a) \\
3.17(d, e)\end{array}$ \\
\hline Globorotalia crassaformis & $\begin{array}{l}\text { C2An.2n (late Mammoth, early Kaena) } \\
\text { (Mediterranean) }\end{array}$ & $3.17(d, e)$ \\
\hline Globorotalia crassaformis ${ }^{\S \S}$ & C2An.1n (late Gauss) (Mediterranean) & $3.00(d, e)$ \\
\hline Globorotalia crassaformis & C2An.1n (late Gauss) (Mediterranean) & $2.92(d, e)$ \\
\hline $\begin{array}{l}\text { Neogloboquadrina atlantica } \\
\text { (Mediterranean Pliocene entry) }\end{array}$ & C2An.In (Mediterranean) $\left(\delta^{18} \mathrm{O}\right.$ stage 110$)$ & $2.72(k)$ \\
\hline Globorotalia pertenuis LAD & Top Gauss Subchron & $2.60(a)$ \\
\hline Globorotalia truncatulinoides FAD & $\begin{array}{l}\text { Gauss/Matuyama boundary (southwest Pacific) } \\
\text { Just below Olduvai Subchron } \\
\text { Just below Olduvai Subchron (Mediterranean) }\end{array}$ & $\begin{array}{l}2.58(l) \\
2.00(a) \\
2.00(i, j, k)\end{array}$ \\
\hline
\end{tabular}


TABLE 5. (continued)

\begin{tabular}{|c|c|c|}
\hline Datum event & Magnetic polarity & $\begin{array}{c}\text { Age } \\
(\mathrm{Ma})^{\star}\end{array}$ \\
\hline Neogloboquadrina atlantica LAD & $\begin{array}{l}\text { Early Matuyama } \\
\text { Early Matuyama (Mediterranean) }\left(\delta^{18} \mathrm{O} \text { stage } 96\right)\end{array}$ & $\begin{array}{l}2.41(\mathrm{~b}) \\
2.41(\mathrm{k}, \mathrm{m})\end{array}$ \\
\hline Globorotalia puncticulata LAD & $\begin{array}{l}\text { Early Matuyama (Atlantic Ocean) } \\
\text { Early }\end{array}$ & $\begin{array}{l}2.41(n) \\
2.41(j, k)\end{array}$ \\
\hline $\begin{array}{l}\text { Pulleniatina (local reappearance, } \\
\text { Atlantic Ocean) }\end{array}$ & Early Matuyama (below Reunion Subchron) & $2.30(a)$ \\
\hline Globorotalia miocenica LAD & $\begin{array}{l}\text { Early Matuyama (below Reunion Subchron) } \\
\text { (Atlantic Ocean only) }\end{array}$ & $2.30(a)$ \\
\hline Globorotalia exilis LAD & Reunion Subchron (Atlantic Ocean only) & $2.15(a)$ \\
\hline Globorotalia inflata (reappearance) & C2r.1r (Mediterranean) & $1.99(k)$ \\
\hline Sphaeroidinella dehiscens (local LAD) & C2r.1r (Mediterranean & $1.98(k)$ \\
\hline $\begin{array}{l}\text { Neogloboquadrina pachyderma } \\
\text { (sinistral) }^{\#}\end{array}$ & $\begin{array}{l}\text { Top Olduvai Subchron (North Atlantic) } \\
\text { Olduvai Subchron (Mediterranean) }\end{array}$ & $\begin{array}{l}1.80(b) \\
1.80(i, j)\end{array}$ \\
\hline Globigerinoides extremus LAD & $\begin{array}{l}\text { Top Olduvai Subchron } \\
\text { Top Olduvai Subchron (Mediterranean) }\end{array}$ & $\begin{array}{l}1.77(a) \\
1.77(i, j)\end{array}$ \\
\hline Globigerina cariacoensis FAD & Top Olduvai Subchron (Mediterranean) & $1.77(i, j)$ \\
\hline \multicolumn{3}{|c|}{ 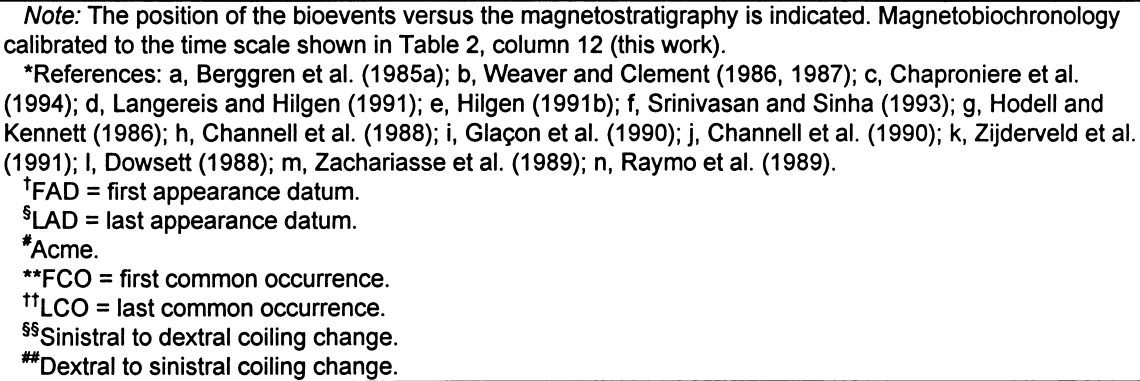 } \\
\hline
\end{tabular}

tion. Thus the Neogene, as a biochron, is framed in the biostratigraphy of the Mediterranean region (Lyell, 1833, 1839, 1857) and it is to this biostratigraphy that information from stratigraphic sequences of

Neogene age, whether in the deep sea or in land sections, must be conveyed if such information is to have more than provincial significance. The means of conveyance is geochronology in the form of a Neogene

TABLE 6. BIOCHRONOLOGY OF PLEISTOCENE PLANKTONIC FORAMINIFERA

\begin{tabular}{|c|c|c|}
\hline Datum event & $\begin{array}{l}\text { Isotope stratigraphy } \\
\text { (magnetic polarity) }\end{array}$ & $\begin{array}{l}\text { Age } \\
(\mathrm{Ma})\end{array}$ \\
\hline Globigerinoides fistulosus $\mathrm{LAD}^{\dagger}$ & Matuyama (just above Olduvai Subchron) & $1.6(a)$ \\
\hline Pulleniatina finalis $\mathrm{LAD}$ & $\begin{array}{l}\text { Matuyama (midway between Jaramillo } \\
\text { and Olduvai Subchrons) }\end{array}$ & $1.40(a, b)$ \\
\hline Globorotalia truncatulinoides excelsa $\mathrm{FAD}^{\S}$ & Middle Jaramillo Subchron (Mediterranean) & $1.00(c, d)$ \\
\hline Globorotalia crassaformis hessi FAD & Basal Brunhes & $0.75(b)$ \\
\hline Globorotalia tosaensis LAD & $\begin{array}{l}\text { Early Brunhes } \\
\text { Latest Brunhes-Jaramillo }\end{array}$ & $\begin{array}{l}0.65(\mathrm{a}, \mathrm{e}) \\
0.8-1.0(\mathrm{~b})\end{array}$ \\
\hline Globorotalia hirsuta FAD & Middle Brunhes $\left(\delta^{18} 0\right.$ stage 12$)$ & $0.45(f)$ \\
\hline Globorotalia flexuosa FAD & Middle Brunhes $\left(\delta^{18} 0\right.$ stage 11$)$ & $0.401(\mathrm{~g})$ \\
\hline Bolliella calida FAD & Late Brunhes $\left(\delta^{18} 0\right.$ stage 7$)$ & $0.22(b)$ \\
\hline Globoquadrina pseudofoliata LAD & Late Brunhes $\left(\delta^{18} 0\right.$ stage 7$)$ & $0.22(b)$ \\
\hline Globorotalia flexuosa LAD & Late Brunhes $\left(\delta^{18} 0\right.$ stage 4$)$ & $0.068(\mathrm{~g})$ \\
\hline \multicolumn{3}{|c|}{$\begin{array}{l}\text { Note: The position of bioevents versus magnetostratigraphy and/or isotopic stratigraphy is indicated. } \\
\text { Magnetobiochronology calibrated to the time scale shown in Table 2, column } 12 \text { (this work). } \\
\text { *References: a, Berggren et al. (1985a); b, Chaproniere et al. (1994); c, Glaçon et al. (1990); d, } \\
\text { Channel et al. (1990); e, Srinivasan and Sinha (1993); f, Pujol and Duprat (1983); g, Joyce et al. (1990). } \\
\text { 'LAD = last appearance datum. } \\
\text { SFAD = first appearance datum. }\end{array}$} \\
\hline
\end{tabular}

time scale (e.g., Berggren et al., 1985a, 1985b; see discussion below). In the section below we review the present status of late Neogene (Pliocene and Pleistocene) chronostratigraphy, with particular reference to the epoch/series boundaries.

The term Neogene (Hörnes, 1853, 1864), like its counterpart, Paleogene (Naumann, 1858), was originally used in a biostratigraphic, rather than chronostratigraphic sense. These terms were introduced to characterize the faunas and floras of the Cenozoic Era. The Neogene was originally created to characterize the faunal (particularly molluscan) and floral changes that denote the middle part of the Cenozoic (beginning, but not clearly delimited, at the Oligocene/Miocene boundary) and that continue to the present day. In the course of preparing a monograph on the molluscan fauna of the Vienna Basin, Hörnes noted that Miocene and Pliocene faunas exhibited a closer relationship to each other than with those of the Eocene, sensu Lyell (he did not recognize a separate Oligocene or Pleistocene at the time). In creating the term Neogene, Hörnes (1853, 1864) referred to the biostratigraphic subdivision of the Tertiary and Quaternary made by the Austrian paleontologist Bronn (1838). Bronn's fifth period (termed the $\mathrm{Mo}$ lasse Gebirge) was subdivided into three groups (termed the Molasse Gruppen). The first was equated with Lyell's Eocene Epoch. The second group, the Molasse Group proper, included the Miocene and Pliocene Epochs sensu Lyell. The Miocene and Pliocene were treated as subunits within the second group and referred to as the untere Abtheilung and obige Abtheilung, respectively. The third Molasse Group contained Alluvial und Quartär-Gebilde zum Theile, the Pleistocene proper (Knochen-Höhlen und der Loss) already having been incorporated into the upper part of his second Molasse Group. The original Neogene concept thus included a priori all post-Eocene molluscan faunas, enclosing rock strata of the Vienna Basin up to and including those in glacial Löss and Diluvian deposits as well as correlative Mediterranean faunas in Sicily, Rhodes, and Cyprus that would now be included in the Pleistocene. It will be recalled that Lyell (1833) created the terms Eocene, Miocene, and Pliocene, and subsequently (Lyell, 1839, 1857) subdivided the latter into an Older (= Pliocene) and Younger (= Pleistocene) Pliocene. He never recognized the term Oligocene.

The Neogene, conceptually, when transferred from a biostratigraphic/biochrono- 


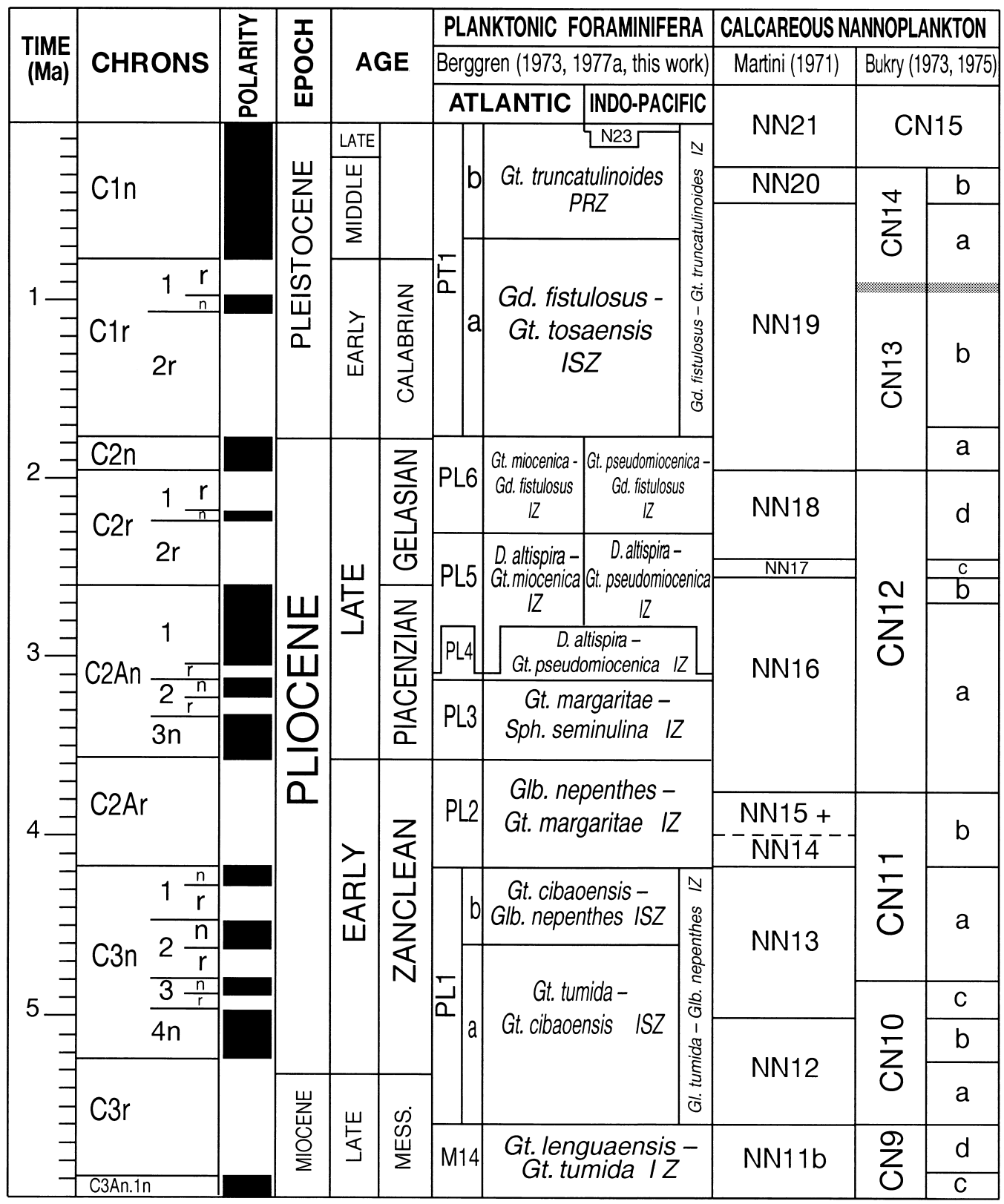

Figure 4. Late Neogene (Pliocene-Pleistocene) (sub)tropical calcareous plankton biostratigraphy and magnetobiochronology. logic (Lyellian) to a chronostratigraphic connotation, includes the stratigraphic record of the Miocene, Pliocene, and Pleistocene. The terms Tertiary and Quaternary are regarded here as inappropriate to the chronostratigraphic hagiography; we prefer a usage that subdivides the Cenozoic Era into two periods/systems, Paleogene and Neogene, with the latter consisting of the Miocene, Pliocene, and Pleistocene Epoch/ Series. Harland et al. (1982, 1990) subdivided the Cenozoic Era into Tertiary ("useful and unambiguous") and Quaternary ("not a satisfactory name") Sub-eras, noting that the Tertiary has been replaced else- where by the terms Paleogene and Neogene (see Bassett, 1985, and Cowie and Bassett, 1989). The Neogene Period was limited to the Miocene and Pliocene Epochs and the Anthropogene or, alternatively, the Pleistogene Period was equated with the Pleistocene and Holocene Epochs. We have provided historical evidence above for including Pliocene and Pleistocene (sensu Lyell) in the Neogene.

Current practice in establishing global chronostratigraphic boundaries links the hierarchical elements in a lock-step equivalency. Thus, the series/epoch boundary coincides with the limits of its included stage/ age boundary in a nested hierarchy, with the lower boundary of a series being drawn at the base of its lowest included stage (see Hedberg, ed., 1978; Schoch, 1989). There are problems associated with this approach, and the Miocene/Pliocene boundary (Messinian/Zanclean stage boundary) serves as a case in point.

\section{The Pliocene Epoch}

The Pliocene is traditionally considered to have begun with the restoration of normal marine conditions in the Mediterranean Basin following the late Miocene (Messinian) 


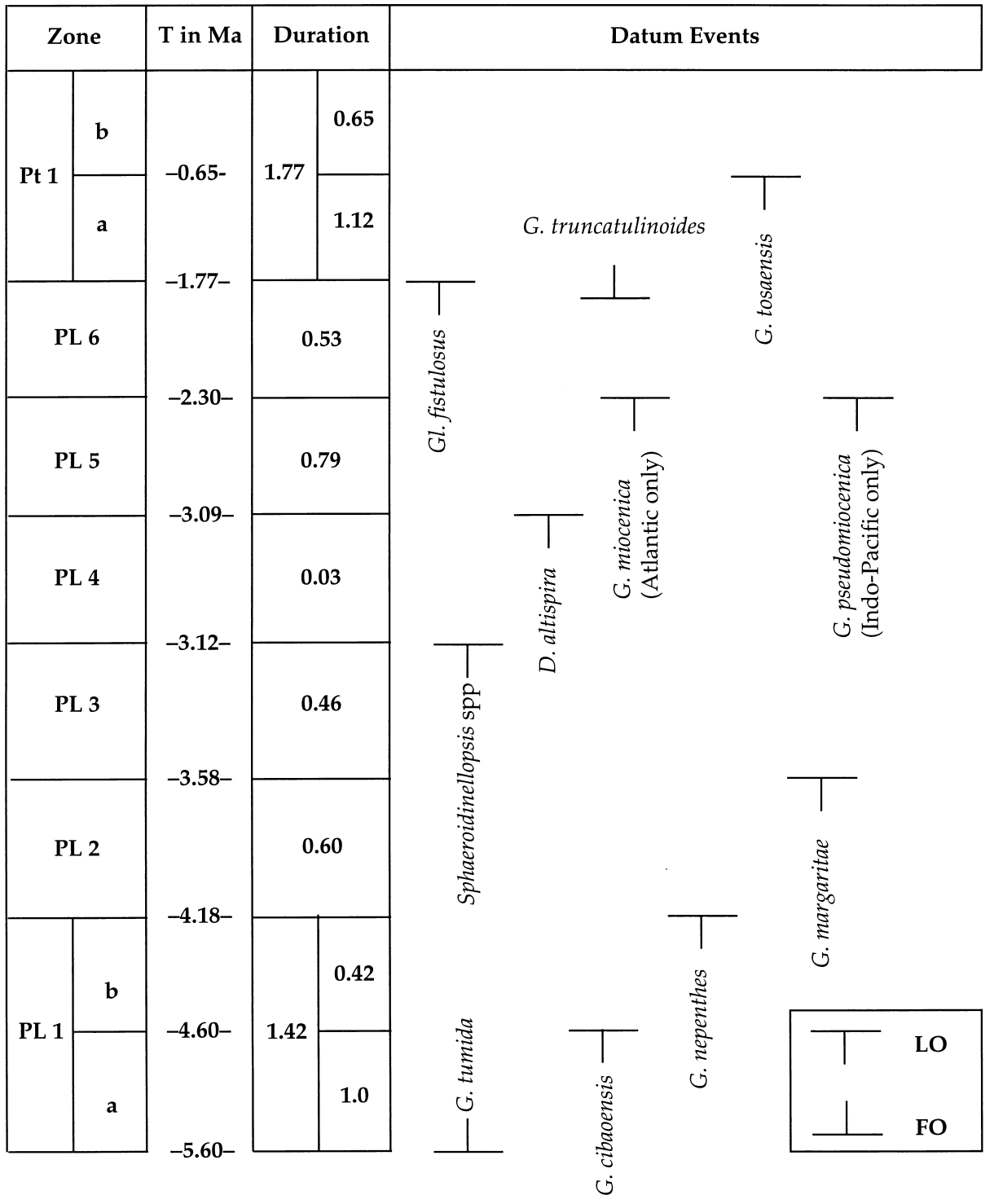

Figure 5. Late Neogene (Pliocene-Pleistocene) (sub)tropical planktonic formainiferal datum events used in developing a standard planktonic formainiferal zonation (Berggren et al., 1995). FO = first occurrence; LO = last occurrence.

desiccation, when the Mediterranean became essentially a basin of interior drainage with only sporadic connection with the global ocean. Cita (1975) proposed the establishment of a boundary stratotype at Capo Rosello (Sicily) at the base of the Trubi Formation (Zanclean Stage), which lies unconformably upon the terminal Messinian brackish water Arenazzola Formation. Recent integrated magnetobiostratigraphic studies (Zijderveld et al., 1986; Hilgen and Langereis, 1988; Hilgen, 1991a, 1991b; Channell et al., 1988) indicate that the base of the Trubi Formation in the Capo Rosello region and Eraclea Minoa sections (Sicily) and Singa and Capo Spartivento sec-
The currently accepted Miocene/Pliocene boundary definition, as the base of the Trubi Formation at Capo Rosello, is difficult to characterize biostratigraphically in the Mediterranean. An assessment of available data on magnetobiostratigraphic correlations of calcareous plankton to the Mediterranean region indicates the following: (1) None of the biostratigraphic events commonly used to estimate the lithostratigraphic position of the Miocene/Pliocene boundary in the global ocean are suitable for precise correlation within the Mediterranean Basin because of biogeographic or environmental exclusion or delayed entry (Rio et al., 1984; 1991). (2) Interpretation of meager biostratigraphic data as well as magnetostratigraphic data from ODP Sites 652 and 654 (Channell et al., 1990) and ODP Leg 138 (Raffi and Flores, in press) indicate that, globally, the base of the Zanclean Stage is probably bracketed by the highest occurrence of Discoaster quinqueramus in the middle part of the lower reversed interval of the Gilbert Chronozone (Chron C3r), and the lowest occurrence of Ceratolithus acutus and highest occurrence of Triquetrorhabdulus rugosus in the uppermost part of the lowest reversed interval of the Gilbert Magnetozone (Chron $\mathrm{C} 3 \mathrm{r}$ ). This latter pair of events occur $\approx 6 \mathrm{~m}$ above the base of the Trubi Formation at Capo Rosello (Cita and Gartner, 1973; Rio et al., 1984) and Capo Spartivento (Raffi, unpubl. data). Note that the $D$. quinqueramus extinction datum is not observed in the Mediterranean because it occurred during the salinity crisis. (3) In terms of planktonic foraminifera, the base of the Zanclean would appear to be bracketed by the lowest occurrence of Globorotalia puncticulata in the Nunivak Subchronozone, and the lowest occurrence of Globorotalia tumida in the lower part of the Gilbert Chronozone (this latter event is not recognized in the Mediterranean).

While the lower limit of the Pliocene (Zanclean Stage) can be recognized magnetostratigraphically, it has been argued (Rio et al., 1991) that the peri-Mediterranean lithologic break between nonmarine (below) and marine (above) sediments at the "boundary" renders this region in general, and the Capo Rosello composite section in particular, unsuitable for definition of a chronostratigraphic boundary as well as unamenable to precise biostratigraphic correlation. Indeed, these authors indicate (Rio et al., 1991) that "in order to properly define the Miocene/Pliocene boundary in a continuous marine sequence, a boundary strato- 
type should be selected from outside the Mediterranean region."

Two approaches to this dilemma have been suggested. One could determine the position of the base of the Zanclean Stage, as defined in the Mediterranean (Sicilian) section(s), in a continuous marine extraMediterranean section and place the Global Stratotype Section and Point (GSSP), the so-called "golden spike", at that level. This approach has been defended recently by Hilgen and Langereis (1993). A second approach would be to identify some recognizable biostratigraphic, magnetostratigraphic, or isotopic event in a continuous marine sequence spanning the interval represented by the unconformity separating the base of the Zanclean and top of the Messinian Stages and place the GSSP "golden spike" there. This alternative has been recommended by Benson and Hodell (1994) in a response to Hilgen and Langereis (1993).

Hilgen and Langereis (1993) propose that the base of the Pliocene can be recognized in the composite Italian stratotype(s) by counting down five precession cycles below the Thvera (C3n.4n) Subchron. Using this approach, they derive an age of $5.32 \mathrm{Ma}$ for the oldest sediments of the Trubi Chalk Formation resting unconformably on the Messinian sediments.

Benson (1994, personal commun. to Berggren) and Benson and Hodell (1994) have discussed the problems of linking the Messinian/Zanclean boundary with the Miocene/Pliocene boundary and render the following observations: (1) The boundary, as currently accepted, is situated close to (if not virtually contiguous with) an unconformity and is based essentially on a local to regional event (i.e., establishment of the neo-Mediterranean Sea following the Messinian Salinity Crisis). Locating the boundary at this level does not allow the sequence of historical events directly prior to the boundary point to be recognized and thus precludes precise biostratigraphic recognition and correlation elsewhere. (2) The boundary in Sicily, as determined by Hilgen and Langereis (1993) by counting down five precession cycles below the base of the Thvera Submagnetozone, is not globally correlatable, and the determination of the boundary on the basis of cyclostratigraphy in the absence of a clearly determined magnetobiostratigraphic and/or isotopic framework renders correlation outside the Mediterranean region tenuous at best. (3) There is a difference between criteria chosen to designate a GSSP (a lithic horizon in a continuous section) and the means by which this horizon may be recognized and correlated away from the type section-usually a fossil datum. Defining the base of the Pliocene as the reestablishment of marine conditions in the Mediterranean establishes this as the criterion by which the base Pliocene is recognized elsewhere, obviously an impossibility. Rather, the Miocene/Pliocene boundary must be defined by a GSSP at a specific horizon, then correlated elsewhere by means of a denotative character (datum event, magnetostratigraphic signature, isotope feature, etc.). (4) Nineteenth-century subdivisions of the Cenozoic by Lyell, d'Orbigny, Mayer-Eymar, and others were imprecise and biostratigraphic and/or lithostratigraphic (Berggren, 1971) in concept, and boundaries were located frequently at unconformities. The boundary, as currently accepted, separates faunas (primarily molluscan) that historically exhibit a "Miocene" and "Pliocene" aspect, respectively; however, Pliocene molluscan faunas continue to exhibit a Miocene aspect well into the Pliocene. Calcareous plankton faunas and floras, characteristic of the early Pliocene, were already becoming established $>1$ m.y. earlier in the Atlantic and Indo-Pacific Oceans (i.e., outside the Mediterranean).

Accordingly, Benson and Hodell (1994) have argued for recognizing the Messinian and Zanclean Stages for what they are, namely the local regional expression of particular historical events in the late Neogene evolution of the Mediterranean, and decoupling them from the question of the Miocene/Pliocene boundary. They propose linking the Miocene/Pliocene boundary with the Chronozone C3r/C3An boundary in a newly proposed boundary stratotype in the Bou Regreg section near Rabat, northwestern Morocco, in a continuous marine sequence of Atlantic facies. (Note that this is essentially the same position of the Miocene/ Pliocene boundary that was thought to correlate with the base of the Zanclean Stage [Cita, 1975; Berggren et al., 1985a, 1985b].)

Hilgen and Langereis (1994) responded as follows: (1) They have not proposed that the Miocene/Pliocene boundary be determined solely on a cyclostratigraphic approach but rather within an astronomically calibrated cyclostratigraphic framework that incorporates an integrated bio-magneto-isotopic stratigraphy. (2) The current boundary is already located very close (within $\approx 100000 \mathrm{yr}$ ) to the next younger (Thvera $=$ C3n.4n Subchron) geomagnetic polarity boundary, which is easily discernible. (3) Magnetostratigraphic data from Bou Regreg is inadequate. (4) It would be more appropriate to determine the precise position of the present boundary using an astronomically calibrated cyclostratigraphic framework in the open ocean and Moroccan sequences and then determine which biostratigraphic datums are most closely associated with this level. The option to define the actual boundary in the Mediterranean (Eraclea Minoa), Moroccan (Bou Regreg), or other location(s) could then be determined at some future date.

This debate has essentially come full circle and we wish to point out that two Miocene/Pliocene boundaries are currently vying for recognition, and ultimately acceptance, by the International Union of Geological Sciences (IUGS) commission on stratigraphy (ICS). They are (1) the base of the Zanclean Stage in the Capo Rosello composite section, which lies within the upper part of the lower (reversed) interval of the Gilbert (Chronozone C3r), and (2) the base of the Gilbert (Chronozone C3r/C3An boundary). The latter boundary has not been formally proposed to the ICS for consideration but is commonly used in paleoceanographic studies.

The Pliocene is generally subdivided into lower (Zanclean) and upper (Piacenzian) stage units, but Rio et al. (1991) have argued recently for a tripartite subdivision into Zanclean (lower) and Piacenzian (middle) Stages and an unnamed unit for the upper Pliocene (the name Gelasian has been proposed recently by Rio et al. (1994) for this stratigraphic interval). They believe that none of the stage names in current use adequately represent the upper Pliocene (ca. 2.6-1.8 $\mathrm{Ma}$ in the chronology adopted here). Both the top of the Zanclean and the base of the Piacenzian stratotypes are marked by unconformities (Rio et al., 1984, 1991). The base of the Piacenzian stratotype is now considered (Rio et al., 1991, 1994) to lie slightly above the highest occurrence of Globorotalia margaritae, between the highest occurrence of Reticulofenestra pseudoumbilica and the highest occurrence of Globorotalia puncticulata (i.e., within the younger part of the Gilbert [Chron C2r]). The top of the Piacenzian stratotype lies between the highest occurrence of Discoaster tamalis and the highest occurrence of $D$. pentaradiatus, within the confines of the relatively short $D$. pentaradiatus (NN17) biochron, which essentially straddles the Gauss/ Matuyama boundary (Rio et al., 1991; Fig. 4). The base of the proposed Gelasian Stage is situated slightly below the highest occurrence of Discoaster pentaradiatus and is correlative with the major growth/expansion of northern hemisphere glaciation near the Gauss/Matuyama boundary.

\section{The Pleistocene Epoch}

Attempts at formulating a coherent and 
unified chronostratigraphy of the Pleistocene have suffered from the climatic overprint that characterizes the late Neogene part of Earth history (see discussions in Hays and Berggren, 1971; Berggren and Van Couvering, 1982). While the formal terminology for the classic glacial/interglacial deposits has been based on northern European sequences, the standard chronostratigraphic terminology is based on Mediterranean (Italian) sections. These demonstrably incomplete stratigraphic sections have been correlated to the continuous oxygen isotope stratigraphy of the oceans for the late Pleistocene (Shackleton and Opdyke, 1973, 1976), which have, in turn, been extended into the early Pleistocene and Pliocene (Ruddiman et al., 1986; Raymo et al., 1989; Joyce et al., 1990).

Following a decade of study and discussions by the International Union for Quaternary Research (INQUA) Subcommission 1a (Pliocene/Pleistocene Boundary) on Stratigraphy and International Geological Correlation Programme Project 41 (Neogene/Quaternary Boundary), a draft proposal on the choice of a boundary stratotype for the Pliocene/Pleistocene boundary was submitted and approved by the INQUA Commission on Stratigraphy and the Subcommission on Quaternary Stratigraphy of the ICS at the 1982 Moscow INQUA Congress. A formal proposal was subsequently submitted to and accepted by the ICS in 1983 (see review by Pasini and Colalongo, 1982), and published 2 yr later (Aguirre and Pasini, 1985) together with the announcement (Bassett, 1985) that the content of the proposal had been formally ratified by the IUGS executive as the GSSP for the base of the Pleistocene.

The "golden spike" was placed at the base of a claystone unit conformably overlying the sapropelic marker bed $e$ in the Vrica section of Calabria in southern Italy. This level has been shown to lie at or near the top of the Olduvai (C2n) Subchronozone. Current attempts to relocate the Pliocene/Pleistocene boundary to coincide with the late Pliocene climatic change at ca. 2.6 Ma are judged here to be inappropriate and to ignore stratigraphic first principles.

With respect to intra-Pleistocene chronostratigraphic subdivision, considerable controversy surrounds the use of lower Pleistocene stage names. As the Calabrian Stage, as stratotypified at Santa Maria di Catanzaro, is probably the approximate stratigraphic correlative of the supposedly suprajacent Sicilian Stage (Ruggieri and Sprovieri, 1979), it has been suggested that the term Calabrian be abandoned and supplanted by the Selinuntian Superstage (with the Santernian, Emilian, and Sicilian as sequential stages within). Ruggieri et al. (1984) subsequently reduced the Selinuntian to stage status and the other three terms to chronozone or substage rank. The Selinuntian had been defined (Ruggieri and Sprovieri, 1979) as the interval between the Pliocene/Pleistocene boundary stratotype and the boundary between the lower and middle Pleistocene (at the top of the Sicilian).

Van Couvering (in press) has argued elegantly and forcefully that this procedure is inappropriate and only exacerbates the problem of early Pleistocene chronostratigraphy. He correctly observes that the boundaries of lower chronostratigraphic units (e.g., Selinuntian) cannot be defined ab initio in terms of the established boundaries of higher units (epoch/series) as this is contrary to logic and the rules of stratigraphic procedure. Thus, the base of the Quaternary, a system of the Cenozoic in common use, is defined at and by the base of the included Pleistocene Series and the Pleistocene, in turn, by the base of its included stage(s). The location of the GSSP in the Calabrian section at Vrica has the serendipitous effect of making that level the Calabrian boundary stratotype.

In the interest of nomenclatorial stability, it is advisable to revise the definition of the Calabrian Stage and preserve a well-known and long-used name. This would appear to be the approach adopted at a recent meeting of the Italian Working Group for Quaternary Stratigraphy (Bari-Taranto, Italy, September 1994). The Santernian would then be the appropriate lowermost substage of the Calabrian Stage. A further step in resolving the chronostratigraphic subdivision of the lower Pleistocene is the recent proposal for the erection of a Santernian/Emilian boundary stratotype $6 \mathrm{~m}$ above marker bed "o" (71.1 $\mathrm{m}$ above the Pliocene/Pleistocene GSSP) in the Vrica section, approximately coincident with the local lowest occurrence of Hyalinea baltica and the lowest occurrence of "large" Gephyrocapsa.

\section{SUMMARY AND CONCLUSIONS}

(1) We recommend a twofold subdivision of the Cenozoic Era/Erathem into the Paleogene (Paleocene, Eocene, Oligocene) and Neogene System/Series based on a review of historical data and modern stratigraphic usage. The Neogene Period/System encompasses all post-Oligocene chronostratigraphic (epoch/series) units: Miocene, Pliocene, Pleistocene, and Holocene.

(2) Astrochronology (or astronomical calibration of climatic proxy records) offers a major step forward in the development of a precise and accurate time scale for the Neogene. The high resolution provided by astrochronology implies that it is no longer necessary to interpolate between a few discrete calibration points to construct a geological time scale. Likewise, it is now possible to unravel the complex phase relationships between various components in the ocean-climate system and between these components and radiation forcing.

(3) Apparent discrepancies between the recently developed late Neogene astronomical time scale and the GPTS have been resolved by means of significant improvements to isotopic dating $\left({ }^{39} \mathrm{Ar} /{ }^{40} \mathrm{Ar}\right)$ of the younger part of this interval (Chrons C1n-C2An) and revised analysis of sea-floor anomaly patterns in the older part (Chrons C2Ar$\mathrm{C} 3 \mathrm{r}$ ). The two chronologies are now concordant back to the Chron C3/C3An boundary at ca. $5.89 \mathrm{Ma}$. The ages of all polarity boundaries are provided in Table 2 together with a historical review of earlier chronologies.

(4) Correlation of Pliocene and Pleistocene calcareous nannoplankton and planktonic foraminiferal biostratigraphic datum events to the GPTS provides a new highresolution magnetobiochronology for regional and global correlations.

(5) Current research on the subdivision of the Pliocene and Pleistocene of the Mediterranean region is devoted to establishing chronostratigraphic stability in the form of stage definitions and stage boundary GSSPs. A formalized threefold subdivision of the Pliocene Series has been proposed recently with the recommendation of adding an upper Pliocene Gelasian Stage to complement the well-founded Zanclean and Piacenzian Stages (lower and middle Pliocene, respectively). The Calabrian Stage appears to be winning back friends as the appropriate name for the lower Pleistocene (with the Santernian, Emilian, and Sicilian as component substages). A GSSP has been proposed for the Santernian/Emilian boundary in the Vrica section, $71 \mathrm{~m}$ above the Pliocene/ Pleistocene boundary GSSP.

\section{POSTSCRIPT}

At the recently convened 10th Regional Committee of Mediterranean Neogene Stratigraphy (RCMNS) in Bucharest, Romania, a meeting of the Subcommission on Neogene Stratigraphy (SNS) was held on 6 September 1995 concerning the placement of the Miocene/Pliocene boundary GSSP (Cita, 1995). An alternative, third proposal was introduced by J.-P. Suc to define the GSSP at a stratigraphic level in the Bou Re- 
greg section correlative with the reestablishment of open marine conditions in the Mediterranean. The SNS agreed to a $2 \mathrm{yr}$ moratorium during which the Capo Rosello and Bou Regreg sections will be examined in greater detail before a final decision is recommended.

\section{ACKNOWLEDGMENTS}

We would like to thank the many colleagues with whom we have discussed various aspects of this study during the course of its preparation, in particular D. Rio, M. P. Aubry, F. Steininger, and J. A. Van Couvering. The last three and R. D. Norris have provided helpful and constructive critiques of earlier versions of the manuscript, as have GSA reviewers S. Gartner, J. Barron, and N. D. Opdyke. Stylistic and organizational improvements were suggested by $\mathrm{R}$. H. Shaver, associate editor of GSA, for which the authors are also sincerely indebted. Research by Berggren was supported by a consortium of oil companies (Amoco, BP, Chevron, Exxon, Marathon, Unocal). Raymo was supported by the National Science Foundation and the Petroleum Research Fund of the American Chemical Society.

\section{REFERENCES CITED}

Aguirre, E., and Pasini, G., 1985, The Pliocene-Pleistocene boundary: Episodes, v. 8, no. 2, p. 116-120.

Backman, J., and Pestiaux, P., 1987, Pliocene Discoaster abundance variations, Deep Sea Drilling Project Site 606: Biochronology and paleoenvironmental implications, in Ruddiman, W. F., Kidd, R. B., Thomas, E., et al., Initial reports of the Deep Sea Drilling Project, Volume 94: Washington, D.C., U.S. Government Printing Office, p. 903-910.

Backman, J., and Shackleton, N., 1983, Quantitative biochronology of Pliocene and early Pleistocene calcareous nanno-
plankton from the Atlantic, Indian and Pacific Oceans: Maplankton from the Atlantic, Indian and Paci

Baksi, A. K., Hsu, V., McWilliams, M. O., and Farrar, E., 1992, ${ }^{40} \mathrm{Ar}{ }^{39} \mathrm{Ar}$ dating of the Brunhes-Matuyama geomagnetic field reversal: Science, v. 256, p. 356-357.

Baksi, A., Hoffman, K. A., and McWilliams, M. O., 1993, Testing the accuracy of the geomagnetic polarity time-scale at 2.5 $\mathrm{Ma}$, utilizing ${ }^{40} \mathrm{Ar}{ }^{39} \mathrm{Ar}$ incremental heating data on wholerock basalts: Earth and Planetary Science Letters, v. 118, p. $135-144$

Bassett, M. G., 1985, Towards a "common" language in stratigraphy: Episodes, v. 8, p. 116-120.

Benson, R. H., and Hodell, D. A., 1994, Comment on "A critical re-evaluation of the Miocene/Pliocene boundary as defined in the Mediterranean" by F. J. Hilgen and C. G. Langereis: Earth and Planetary Science Letters, v. 124, p. 245-250.

Berger, A., and Loutre, M. F., 1991, Insolation values for the climate of the last 10 million years: Quaternary Science Reviews, v. 10 , p. 297-317.

Berggren, W., 1971, Tertiary boundaries, in Funnell, B., and Riedel, W. R., Micropalaeontology of the oceans: Cambridge, United Kingdom, Cambridge University Press, p. 693-809.

Berggren, W. A., and Van Couvering, J. A., 1982, Quaternary, in Robison, R. A., and Teichert, C., eds., Treatise on invertebrate paleontology, Part A: Introduction, fossilization (taphonomy), biogeography and biostratigraphy: Boulder, Colorado, Geological Society of America (and University of Colorado, Geological Society

Berggren, W. A., Kent, D. V., and van Couvering, J. A., 1985a, Neogene geochronology and chronostratigraphy, in Snelling, N. J., ed., The chronology of the geological record: Geological Society of London Memoir 10, p. 211-250.

Berggren, W. A., Kent, D. V., Flynn, J. J., and Van Couvering, J. A., 1985b, Cenozoic geochronology: Geological Society of America Bulletin, v. 96, p. 1407-1418.

Berggren, W. A., Kent, D. V., Obradovich, J. D., and Swisher, C. C., III, 1992, Toward a revised Paleogene geochronology, in Prothero, D. R., and Berggren, W. A., eds., EoceneOligocene climatic and biotic evolution: Princeton, New Jersey, Princeton University Press, p. 29-45.

Berggren, W. A., Kent, D. V., Swisher, C. C., III, and Aubry, M.-P 1995, A revised Cenozoic geochronology and chronostratigraphy, in Berggren, W. A., Kent, D. W., Aubry, M.-P., and Hardenbol, J., Geochronology, time scales and stratigraphic (Society for Sedimentary Geology) Special Publication 54 (in press).

Bronn, H. G., 1838, Lethaea, Geognostica, oder Abbildungen und Beschreibungen der fur die Gebirgsformationen bezechnendsten Versteinerungen: Stuttgart, v. 2, p. 545-1356, $48 \mathrm{pl}$

Calvert, S. E., 1983, Geochemistry of Pleistocene sapropels and associated sediments from the eastern Mediterranean: Oceanologica Acta, v. 6, p. 255-267.

Cande, S. C., and Kent, D. V., 1992, A new geomagnetic polarity time scale for the Late Cretaceous and Cenozoic: Journ Geophysical Research, v. 97, p. 13917-13951.

Cande, S. C., and Kent, D. V., 1995, Revised calibration of the geomagnetic polarity time scale for the Late Cretaceous and Cenozoic: Journal of Geophysical Research, v. 100, no. B4, p. 6093-6095.

Channell, J. E. T., Rio, D., and Thunell, R. C., 1988, Miocene/ Pliocene boundary magnetostratigraphy at Capo Spa tivento, Calabria, Italy: Geology, v. 16, p. 1096-1099.

io, D., Sprovieri, R., and Glaçon, G., 1990, Biomagnetostratigraphic correlations from Leg 107 in the . ceedings of the Ocean Drilling Program, science results, Leg 107: College Station, Texas, Ocean Drilling Program, p. 669-682.

Chaproniere, G. C. H., Styzen, M. J., Sager, W. W., Nishi, H Quinterno, P., and Abrahamsen, N., 1994, Late Neogene biostratigraphic and magneto-biostratigraphic synthesis, Leg 135, in Hawkins, J., Parson, L., Allan, J., et al.: Proceedings, Ocean Drilling Program, scientific results, Leg 135: College Station, Texas Ocean Drilling Program, p. $857-877$

Cita, M. B., 1975, The Miocene/Pliocene boundary: History and definition, in Saito, T., and Burckle, L. H., Late Neogene Epoch boundaries: New York, Micropaleontology Press, Special Publication 1, p. 1-30.

Cita, M.B., 1995, SNS Workshop on Miocene/Pliocene boundary, in Cita, M.B., ed., International Union of Geological Sciences, International Commission on Stratigraphy, Subcommission on Neogene Stratigraphy: Neogene Newsletter, no. 2, p. $3-78$.

Cita, M. B., and Gartner, S., 1973, Studi sul Pliocene e sugli strati del passagio dal Miocene al Pliocene, IV. The stratotype Zanclean, foraminiferal and nannofossil biostratigraphy: Rivista Italiana Paleontologia Stratigrafia, v. 79, p. 503-558.

Cita, M. B., Vergnaud-Grazzini, C., Robert, C., Chamley, H. Ciaranfi, N., and d'Onofrio, S., 1978, Paleoclimatic record of a long deep-sea core from the eastern Mediterranean: Quaternary Research, v. 8, p. 205-235.

Cowie, J. W., and Bassett, M. G., 1989. International Union of Geological Sciences 1989 stratigraphic chart: Episodes, v. 12 , no. 2 , insert.

Cox, A., and Dalrymple, G. B., 1967, Statistical analysis of geomagnetic reversal data and the precision of potassium-argon dating: Journal of Geophysical Research, v. 72, p. 2603-2614.

Cox, A., Doell, R. R., and Dalrymple, G. B., 1963, Geomagnetic polarity epochs and Pleistocene geochronometry: Nature, v. 198 , p. $1049-1051$

Cox, A., Doell, R. R., and Dalrymple, G. B., 1964, Reversals of Earth's magnetic field: Science, v. 144, p. 1537-1543.

Dalrymple, G. B., and Lanphere, M. A., 1969. Potassium-argon dating: San Francisco, W. H. Freeman, 258 p.

Deino, A. L., Hausback, B. P., Turrin, B. T., and McKee, E. H., 1989 , New ${ }^{40} \mathrm{Ar}{ }^{39} \mathrm{Ar}$ ages for the Spearhead and Civet Cat Members of the Stonewall Flat Tuff, Nye Co., Nevada [abs.]: EOS (American Geophysical Union Transactions), v. 70 EOS $(A$

Dowsett, H., 1988, Diachrony of late Neogene microfossils in the southwest Pacific Ocean: Application of the graphic correation method: Paleoceanography, v.3, no. 2, p. 209-222.

Driever, B. W. M., 1988, Calcareous nannofossil biostratigraphy and paleoenvironmental interpretation of the Mediterra$245 \mathrm{p}$.

miliani, C., 1955, Pleistocene temperatures: Journal of Geology, v. 63 , p. $538-578$

Fechtig, H., and Kalbitzer, S., 1966, The diffusion of argon in potassium-bearing solids, in Schaeffer, O. A., and Zahringer, J., eds., Potassium-argon dating: New York, SpringerVerlag, p. 68-107.

Gale, N. H., 1982, The physical decay constants, in Odin, G. S., ed., Numerical dating in stratigraphy: New York, John Wiley and Sons, p. 107-122.

Glacon, G., and nine others, 1990, Planktonic foraminiferal events and stable isotope records in the upper Miocene, Site 654 in Kastens, K., Mascle, J., et al.: Proceedings of the Ocean in Kastens, K., Mascle, J., et al.: Proceedings of the Ocean tion, Texas, Ocean Drilling Program, p. 415-427.

Haq, B. U., and Takayama, T., 1984, Neogene calcareous nannoplankton datum planes and their calibration to magnetostratigraphy, in Ikebe, N., and Tsuchi, R., eds., Pacific Neogene datum planes: Tokyo, University of Tokyo Press, Contribution to Biostratigraphy and Chronology, p. 27-32.
Harland, W. B., Cox, A. V., Llewellyn, P. G., Pickton, C. A., Smith, A. G., and Wallters, R., 1982, A geologic time scale: Cambridge, United Kingdom, Cambridge University Press, $131 \mathrm{p}$

Harland, W. B., Armstrong, R. L., Cox, A. V., Craig, L. E., Smith, A. G., and Smith, D. G., 1990, A geologic time scale 1989: Cambridge, United Kingdom, Cambridge University Press, $263 \mathrm{p}$

Hays, J. D., and Berggren, W. A., 1971, Quaternary boundaries and correlations, in Funnell, B. F., and Riedel, W. R., eds, Micropaleontology of the oceans: Cambridge, United Kingdom, Cambridge University Press, p. 669-691.

Hays, J. D., Imbrie, J., and Shackleton, N. J., 1976, Variations in the Earth's orbit: Pacemaker of the ice ages: Science, v. 194 p. $1121-1131$

Hedberg, H. D., editor, 1978, International stratigraphic guide: A guide to stratigraphic classification, terminology and procedure: New York, John Wiley and Sons, $200 \mathrm{p}$.

Heirtzler, J. R., Dickson, G. O., Herron, E. M., Pitman, W. C., III, and Le Pichon, X., 1968, Marine magnetic anomalies, geomagnetic field reversals, and motions of the ocean floor and continents: Journal of Geophysical Research, v. 73, p. 2119-2136.

Hilgen, F. J. 1987, Sedimentary rhythms and high-resolution chronostratigraphic correlations in the Mediterranean Pliocene: Newsletters on Stratigraphy, v. 17, p. 109-127.

Hilgen, F. J., 1990, Closing the gap in the Plio-Pleistocene boundary stratotype sequence of Crotone (southern Italy) Newsletters on Stratigraphy, p. 22, p. 43-51.

Hilgen, F. J., 1991a, Astronomical calibration of Gauss to Matuyama sapropels in the Mediterranean and implication for the geomagnetic polarity time scale: Earth and Planetary Science Letters, v. 104, p. 226-244.

Hilgen, F. J., 1991b, Extension of the astronomically calibrated (polarity) time scale to the Miocene/Pliocene boundary

Hilgen, F. J. and Langereis, C. Letters, v. 107, p. 349-368. cene-Pliocene boundary in the Capo Rosello area: Earth and Planetary Science Letters, v. 91, p. 214-222.

Hilgen, F. J., and Langereis, C. G., 1989, Periodicities of $\mathrm{CaCO}_{3}$ cycles in the Mediterranean Pliocene: Discrepancies with the quasi-periods of the Earth's orbital cycles?: Terra Nova, v. 1, p. $409-415$

Hilgen, F. J., and Langereis, C. G., 1993, A critical re-evaluation of the Miocene/Pliocene boundary as defined in the Mediterranean: Earth and Planetary Science Letters, v. 118 p. 167-179.

Hilgen, F. J., and Langereis, C. G., 1994, Reply to comment on "A critical re-evaluation of the Miocene/Pliocene boundary as defined in the Mediterranean" by R. H. Benson and D. A Hodell: Earth and Planetary Science Letters, v. 124, p. 251-252.

Hilgen, F. J., Lourens, L. J., Berger, A., and Loutre, M. F., 1993, Evaluation of the astronomically calibrated time scale for the late Pliocene and earliest Pleistocene: Paleoceanography, v. 8, p. 549-565.

Hodell, D. A., and Kennett, J. P., 1986, Late Miocene-early Pliocene stratigraphy and paleoceanography of the South Atlantic and southwest Pacific Oceans: A synthesis: Paleoceanography, v. 1 , no. 3 , p. $285-311$

Hörnes, M., 1853, Mittheilung an Professor BRONN gerichtet, Wien, 3 Oktober 1853: Neues Jahrbuch für Mineralogie, Geologie, Geognosie und Petrefaktenkunde, p. 806-810.

Hörnes, M., 1864, Die fossilen Mollusken des Tertiaerbeckens von Wien: Jahrbuch der geologischen Reichssanstalt, v. 14 p. 509-514.

Imbrie, J., and eight others, 1984, The orbital theory of Pleistocen climate: Support from a revised chronology of the marine $\delta^{18} \mathrm{O}$ record, in Berger, A., et al., Milankovitch and climate,
Part 1: Dordrecht, Netherlands, D. Riedel Publishing Co., p. 269-305.

Izett, G. A., and Obradovich, J. D., 1991, Dating of the MatuyamaBrunhes boundary based on ${ }^{40} \mathrm{Ar}-{ }^{39} \mathrm{Ar}$ ages of the Bishop Tuff and Cerro San Luis Rhyolite: Geological Society of America Abstracts with Programs, v. 23, no. 5, p. A106.

America Abstracts with Programs, ${ }^{40}$ 23, no. 5, p. A106.
Izett, G. A., and Obradovich, J. D., $1992,{ }^{30} \mathrm{Ar}-{ }^{39} \mathrm{Ar}$ dating of the Jaramillo normal subchron and the Matuyama and Brunhes boundary: U.S. Geological Survey Open-File Report 92 699, $22 \mathrm{p}$.

Izett, G. A. Obradovich, J. D., and Menhert, H. H., 1988, The Bishop ash bed (middle Pleistocene) and some other Pliocene and Pleistocene chemically and mineralogically similar ash beds in California, Nevada, and Utah: U.S. Geologica Survey Bulletin 1175, p. 1-37

Johnson, R. G., 1982, Brunhes-Matuyama magnetic reversal dated at 790,000 yr B.P. by marine-astronomical correlations: Quaternary Research, v. 17, p. 135-147.

Joyce, J. E., Tjalsma, L. R. C., and Prutzman, J. M., 1990, Highresolution planktic stable isotope record and spectral analysis for the last 5.35 m.y.: Ocean Drilling Program Site 625 Northeast Gulf of Mexico: Paleoceanography, v. 5, no. 4, p. $507-529$.

Langereis, C. G., and Hilgen, F. J., 1991, The Rossello composite: A Mediterranean and global reference section for the early to early late Pliocene: Earth and Planetary Science Letters, v. 104 , p. $211-225$.

Langereis, C. G., vanHoof, A. A. M., and Hilgen, F. J., 1994 Steadying the rates: Nature, v. 369 , p. 615 .

Linssen, J. H., 1988, Preliminary results of a study of four successive sedimentary geomagnetic reversal records from th Mediterranean (upper Thvera, lower and upper Sidufjall, 
lower Nunivak): Physics of the Earth and Planetary Interiors, v. 52, p. 207-231.

Lyell, C., 1833, Principles of geology (first edition): London, John Murray, v. 3, 398 p.

Lyell, C., 1839, Nouveaux éléments de geologie: Paris, PitoisLevranet, $648 \mathrm{p}$.

Lyell, C., 1857, Supplement to the fifth edition: London, John Murray, $40 \mathrm{p}$.

Mankinen, E. A., and Dalrymple, G. B., 1979, Revised geomagnetic polarity time scale for the interval $0-5 \mathrm{~m}$ y. B.P. Journetic polarity time scale for the interval $0-5$ m.y.
nal of Geophysical Research, v. 84, p. $615-626$.

Mankinen, E. A., and Gromme, C. S. 1982, Paleomagnetic data from the Coso Range, California and current status of the Cobb Mountain normal geomagnetic polarity event: Geophysical Research Letters, v. 9, p. 1279-1282. T. C., and Shackleton, N. J., 1987, Age dating and the orbital theory of the ice ages: Development of a high-resolution 0 to 300,000-year chronostratigraphy: Quaternary Research, v. 27 , p. $1-29$.

Mazzei, R., Raffi, I., Rio, D., Hamilton, N., and Cita, M. B., 1979, Calibration of the late Neogene calcareous plankton datum planes with the paleomagnetic record of Site 397 and correlation with Moroccan and Mediterranean sections, in von Rad, U., Ryan, W. B. F., et al., Initial reports of the Deep Sea Drilling Project, Volume 47, pt. 1: Washington, D.C., U.S. Government. Printing Office, p, 375-389.

McDougall, I., 1971, The geochronology and evolution of the young volcanic island of Reunion, Indian Ocean:
Geochimica et Cosmochimica Acta, v. 35, p. 261-288.

McDougall, I., 1979, The present status of the geomagnetic polarity time scale, in McElhinny, M. W., ed., The Earth: Its origin, structure, and evolution: New York, Academic Press, p. 543-566.

McDougall, I., Brown, F. H., Cerling, T. E., and Hillhouse, J. W., 1992, A reappraisal of the geomagnetic polarity time scale to 4 Ma using data from the Turkana Basin, East Africa: Geophysical Research Letters, v. 19, p. 2349-2352.

McDowell, F. W., 1983, K-Ar dating: Incomplete extraction of radiogenic argon from alkali feldspar: Isotope Geoscience, v. 1 , p. $119-126$

McKenzie, J. A., Jenkyns, H. C., and Bennet, G. G., 1979, Stable isotope study of the cyclic diatomite-claystones from the Tripoli Formation, Sicily: A prelude to the Messinian salin-
ity crisis: Palaeogeography, Palaeoclimatology, Palaeoecology, v. 29 , p.125-141.

Meulenkamp, J. E., Driever, B. W. M., Jonkers, H. A., Spaak, P., Zachariasse, W. J., and van der Zwaan, G. J., 1979, Late Miocene-Pliocene climatic fluctuations and marine cyclic sedimentation patterns: Annales Géologique Pays Hellésedimentation patterns:
nique, v. II, p. 831-842.

Musset, A. E., 1969, Diffusion measssurements and the potassiumargon method of dating: Royal Astronomical Society Geophysical Journal, v. 18 , p. 257-303.

Naumann, C. F., 1858, Lehrbuch der Geognosie (second edition): Leipzig, Englemann, v. 3, 576 p.

Obradovich, J. D., and Izett, G. A., 1992, The geomagnetic polarity time scale (GPTS) and the astronomical time scale (ATS) now in near accord [abs.]: EOS (American Geophysical Union Transactions), v. 73 , no. 44 , p. 630

Obradovich, J. D., Izett, G. A., Reynolds, R. L., and Mankinen, E. A., in press, Revisions of ages of geomagnetic polarity subchrons within the Matuyama Chron: Earth and Planetary Science Letters.

Pasini, G.-C., and Colalongo, M. L., 1982, Status of research on the Vrica section (Calabria, Italy), the proposed Neogene/Quaternary boundary-stratotype section, in 1982: Report presented at XI INQUA Congress, Moscow, 1982: Bologna, Italy, Pitsagora-Tecnoprint, $75 \mathrm{p}$.

Pisias, N. G., and Moore, T. C., 1981, The evolution of Pleistocene climate: A time series approach: Earth and Planetary Science Letters, v. 52, p. $450-458$.

Pisias, N., Martinson, D. G., Moore, T. C., Shackleton, N. J., Prell, W., Hays, J. D., and Boden, G., 1984, High resolution stratigraphic correlations of benthic oxygen isotopic records spanning the last 300,000 years: Marine Geology, v. 56, p. 119-136.

Postma, G., Hilgen, F. J., and Zachariasse, W. J., 1993, Precessionpunctuated growth of a late Miocene submarine-fan lobe on Gavdos (Greece): Terra Nova, v. 5, p. 438-444.

Prell, W., Imbrie, J., Martinson, D. G., Morley, J., Pisias, N., Shackleton, N. J., and Streeter, S., 1986, Graphic correlation of oxygen isotope stratigraphy application to the late Quaternary: Paleoceanography, v. 1, p. 137-162.

Pujol, C., and Duprat, J., 1983, Quaternary planktonic foraminifers of the southwestern Atlantic (Rio Grande Rise) Deep Sea Drilling Project Leg 72, in Barker, P. F., Carlson, R. L., Johnson, D. A., et al.: Initial reports of the Deep Sea Drilling Project, Volume 72: Washington, D.C., U.S. Government Printing Office, p. 601-615.

Raffi, I., and Flores, J. A., in press, Pleistocene through Miocene calcareous nannofossils from eastern equatorial Pacific, Leg 138, in Pisias, N. G., Mayer, L. A., Janecek, T. R., et al., 138, in Pisias, N. G., Mayer, L. A., Janecek, T. R., et al.,
Proceedings of the Ocean Drilling Program, Scientific Results, Leg 138: College Station, Texas, Ocean Drilling Program.

Raffi, I., Backman, J., Rio, D., and Shackleton, N. J., 1993, PlioPleistocene and late Pliocene nannofossil biostratigraphy and calibration to oxygen isotope stratigraphies from Deep Sea Drilling Project Site 607 and Ocean Drilling Program Site 677: Paleoceanography, v. 8, no. 3, p. 387-408.

Raffi, I., Rio, D., d'Atri, A., Fornaciari, E., and Rocchetti, S., in press, Quantitative distribution patterns and biomagnetostratigraphy of middle and late Miocene calcareous nannofossils from the equatorial Indian and Pacific Oceans (Legs 115, 130 and 138), in Pisias, N. G., Mayer, L. A., Janecek, T. R., et al.: Proceedings of the Ocean Drilling Program, Scientific Results, Leg 138: College Station, Texas, Ocean Drilling Program.

Raymo, M. E., Ruddiman, W. F., Backman, J., Clement, B. M., and Martinson, D. G., 1989, Late Pliocene variation in
northern hemisphere ice sheets and North Atlantic deep northern hemisphere ice sheets and North Atlantic deep

Renne, P., Walter, R. C., Verosub, K. L., Sweitzer, M., and Aronson, J. L., 1992, Magnetostratigraphy and the ${ }^{40} \mathrm{Ar} /{ }^{39} \mathrm{Ar}$ dating of the Hadar Fm., Ethiopia: GPTS calibration within the Gauss Chron [abs.]: EOS (American Geophysical Union Transactions): v. 73 , no. 44 , p. 633

Renne, P., Walter, R. C., Verosub, K., Sweitzer, M., and Aronson, J., 1993, New data from Hadar (Ethiopia) support orbitally tuned time scale to $3.3 \mathrm{Ma}$ : Geophysical Research Letters, v. 20 , p. $1067-1070$

Rio, D., Sprovieri, R., and Raffi, I., 1984, Calcareous plankton biostratigraphy and biochronology of the Pliocene-Pleistocene succession of the Capo Rosello area, Sicily: Marine Micropaleontology, v. 9, p. 135-180

Rio, D., and eight others, 1989, Stratigraphy and depositional history of the Pliocene Bianco section, Calabria, southern Italy: Palaeogeogra $85-105$.

Rio, D., Raffi, I., and Villa, G., 1990, Pliocene-Pleistocene calcareous nannofossil distribution patterns in the western Mediterranean, in Kastens, K. A., Mascle, J., et al.: Proceedings of the Ocean Drilling Program, Scientific Results, Leg 107: College Station, Texas, Ocean Drilling Program, p. 513-533.

Rio, D., Sprovieri, R., and Thunell, R., 1991, Pliocene-Pleistocene chronostratigraphy: A re-evaluation of Mediterranean type sections: Geological Society of America Bulletin, v. 103, p. $1049-1058$

Rio, D., Sprovieri, R., and DiStefano, E., 1994, The Gelasian Stage: A new chronostratigraphic unit of the Pliocene Series: Rivisita Italiana Paleontologia Stratigraphia, v. 100, no. 1, p. 103-124

Rio, D., Raffi, I., and Backman, J., in press, Calcareous nannofossil biochronology and the Pliocene-Pleistocene boundary, in Van Couvering, J. A., ed., The Quaternary boundary-Definition and worldwide correlation, final report of the International Geological Correlation Programme 41: "Neogene/Quaternary Boundary": Cambridge, United Kingdom, Cambridge University Press.

Rohling, E. J., and Gieskes, W. W. C., 1989, Late Quaternary changes in Mediterranean intermediate water density and formation rate: Paleoceanography, v. 4, p. 531-545.

Rossignol-Strick, M., 1983, African monsoons, an immediate climatic response to orbital insolation: Nature, v. 30, p. 46-49.

Ruddiman, W. F. Raymo, M., and McIntyre, A 1986, Matuyama 41,000-year cycles: North Atlantic Ocean and northern hemisphere ice sheets: Earth and Planetary Science Letters, v. 80 , p. $117-129$

Ruddiman, W. F., Raymo, M. E., Martinson, D. G., Clement, B. M., and Backman, J., 1989, Pleistocene evolution: Northern hemisphere ice sheets and North Atlantic Ocean: Paleoceanography, v. 4, p. 353-412.

Ruggieri, G., and Sprovieri, R., 1979, Selinuntiano, nuovo superpiano per il Pleistocene inferiore: Societa Geologico Ita iano Bolletino, v. 96 , p. $797-802$.

Ruggieri, G., Rio, D., and Sprovieri, R., 1984, Remarks on the chronostratigraphic classification of lower Pleistocene: Societa Geologico Italiano Bolletino, v. 53, p. 251-259.

Ryan, W. B. F., 1972, Stratigraphy of late Quaternary sediments in the eastern Mediterranean, in Stanley, D. J., The Mediterranean Sea: A natural sedimentation laboratory: Strouds-
burg, Pennsylvania, Dowden, Hutchinson and Ross, burg, Pen $146-169$

Schoch, R. M., 1989, Stratigraphy: Principles and methods: New York, Van Nostrand Reinhold, $375 \mathrm{p}$

Selli, R., and 14 others, 1977, The Vrica section (Calabria): A potential Neogene-Quaternary boundary stratotype: Giornali Geologia, v. 41, p. 181-204.

Shackleton, N. J., and Opdyke, N. D., 1973, Oxygen isotope and palaeomagnetic stratigraphy of equatorial Pacific core V28238: Oxygen isotope temperatures and ice volumes on a 105 and 106 year scale: Quaternary Research, v. 3, p. 39-55.

Shackleton, N. J., and Opdyke, N. D., 1976, Oxygen isotope and paleomagnetic stratigraphy of Pacific core V28-239 late Pliocene to latest Pleistocene, in Cline, R. M., and Hays, J. D., eds., Investigations of late Quaternary paleoceanog-
raphy and paleoclimatology: Geological Society of America Memoir 145, p. 449-464.

Shackleton, N. J., Berger, A., and Peltier, W. R., 1990, An alternative astronomical calibration of the lower Pleistocene timescale based on ODP Site 677: Royal Society of Edinburgh Transactions: Earth Sciences, v. 81, p. 251-261.

Shackleton, N. J., Crowhurst, S., Hagelberg, T., Pisias, N., and Schneider, D. A., in press, A new late Neogene timescale: Schneider, D. A., in press, A new late Neogene timescale:
Application to ODP Leg 138 sites, in Pisias, N., Mayer, L., Application to ODP Leg 138 sites, in Pisias, N., Mayer, L.,
Janecek, T., et al.: Proceedings of the Ocean Drilling ProJanecek, T., et al.: Proceedings of the Ocean Drilling Pro-
gram, Scientific Results, Leg 138: College Station, Texas, gram, Scientific Results, Leg 138: Coll

Spell, T. L., and McDougall, I., 1992, Revisions to the age of the Brunhes-Matuyama boundary and the Pleistocene geomagnetic polarity timescale: Geophysical Research Letters, v. 19 , p. $1181-1184$

Srinivasan, M. S., and Sinha, D. K., 1993. Late Neogene planktonic foraminiferal events of the southwest Pacific and Indian Ocean: A comparison, in Tsuchi, R., and Ingle, J. C., Jr., eds., Pacific Neogene environment, evolution and events: Tokyo, University of Tokyo Press, p. 203-220.

Tauxe, L., Opdyke, N. D., Pasini, G., and Elmi, C., 1983, Age of the Plio-Pleistocene boundary in the

Tauxe, L., Deino, A. D., Behernsmeyer, A. K., and Potts, R., 1992, Pinning down the Brunhes/Matuyama and upper Jaramillo boundaries: A reconcilliation of orbital and isotopic time scales: Earth and Planetary Science Letters, v. 109, scales: Earth
p. $561-572$.

Thierstein, H. R., Geitzenauer, K. R, and Molfino, B., 1977, Global synchroneity of late Quaternary coccolith datum levels: Validation by oxygen isotopes: Geology, v. 5 p. $400-404$.

Thunell, R. C., Williams, D. F., and Belyea, P. R., 1984, Anoxic events in the Mediterranean Sea in relation to the evolution of late Neogene climates: Marine Geology, v. 59, p. 105-134.
i, G. B., and Ricci Luchi, F., 1977, Algal crusts, autochthonous and clastic gypsum in a cannibalistic evaporite basin: A case history from the Mediterranean and northern Apennines: Sedimentology, v. 24, p. 211-244.

Van Couvering, J. A., in press, Preface: The new Pleistocene, in Van Couvering, J. A., ed., The Pleistocene boundary and the beginning of the Quaternary, final report of the International Geological Correlation Programme Project 41, "Neogene/Quaternary Boundary": Cambridge, United Kingdom, Cambridge University Press.

Van Hoof, A. A. M., and Langereis, C. G., 1991, Reversal records in marine marls and delayed acquisition of remanent magnetization: Nature, v. 351, p. 223-225.

Van Hoof, A. A. M., and Langereis, C. G., 1992, The upper Kaena sedimentary geomagnetic reversal record from southern

Van Hoof, A. A. M., van Os, B. J. H. Rademake. J. G., La gereis, C. G., and de Lange, G. J., 1993, A paleomagnetic and geochemical record of the upper Cochiti and two subsequent precessional cycles from southern Sicily (Italy) Earth and Planetary Science Letters, v. 11, p. 235-250.

Vergnaud-Grazzini, C., Ryan, W. B. F., Stable isotope fractionation, climatic change and episodic stagnation in the eastern Mediterranean during the late Quaternary: Marine Micropaleontology, v. 2, p. 353-370.
hallen, P. J. J. M., 1987, Early development of Bulimina mar

ginata in relation to paleoenvironmental changes in the Mediterranean: Koninklijke Nederlandse Akademie de Wetenschappen, ser. B, v. 90 , p. $161-180$

Walter, R. C., Manega, P. C., Hay, R. L., Drake, R. E., and Curtis, G. H., 1991, Laser-fusion ${ }^{40} \mathrm{Ar} /{ }^{39} \mathrm{Ar}$ dating of bed 1, Olduvai Gorge, Tanzania: Nature, v. 35, p. 145-147.

Walter, R. C., Deino, A., Renne, P., and Tauxe, L. 1992 , Refining Plio-Pleistocene GPTS using laser-fusion ${ }^{40} \mathrm{Ar} /{ }^{39} \mathrm{Ar}$ tephrachronology: Case studies from the East African rift [abs.] no. 43 , p. 629.

Weaver, P. E., and Clement, B. M., 1986, Synchroneity of Pliocene planktonic foraminiferal datums in the North Atlantic: Marine Micropaleontology, v. 10, p. 295-307.

Weaver, P. P. E., and Clement, B. M., 1987, Magnetobiostratigraphy of planktonic foraminiferal datums, Deep Sea Drilling Project Leg 94, North Atlantic, in Ruddiman, W. F. Kidd, R. B., Thomas, E., et al.: Initial reports of the Deep Sea Drilling Project, Volume 94: Washingt
Government Printing Office, p. 815-829.

Weltje, G., and deBoer, P., 1993, Astronomically induced paleoclimatic oscillations reflected in Pliocene turbidite deposits on Corfu (Greece): Implications for the interpretation of higher order cyclicity in ancient turbidite systems: Geology, v. 21 , p. $307-310$

Williams, D. F., Thunell, R., Tappa, E., Rio, D., and Raffi, I., 1988 Chronology of the Pleistocene oxygen isotope record 0-1.88 m.y. B.P.: Palaeogeography, Palaeoclimatology, Palaeoecology, v. 6, p. 221-240.

Wilson, D., 1993, Confirmation of the astronomical calibration of the magnetic polarity timescale from sea-floor spreadin rates: Nature, v. 364, p. $788-790$.

Zachariasse, W. J., Zijderveld, J. D. A., Langereis, C. G., Hilgen, F. J., and Verhallen, P. J. J. M., 1989, Early late Pliocene biochronology and surface water temperature variations in the Mediterranean: Marine Micropaleontology, v. 14, p. $339-355$.

Zijderveld, J. D. A., Zachariasse, W. J., Verhallen, P. J. J. M., and Hilgen, F. J., 1986, The age of the Miocene-Pliocene boundary: Newsletters in Stratigraphy, v. 16, p. 169-181.

Zijderveld, J. D. A., Hilgen, F. J., Langereis, C. G., Verhallen, P. J. J. M., and Zachariasse, W. J., 1991, Integrated magnetostratigraphy and biostratigraphy of the upper Pliocenelower Pleistocene from the Monte Singa and Crotone areas in Calabria, Italy: Earth and Planetary Science Letters, v. 106 , p. $97-174$

Manuscript Received by the Society May 9, 1994

REVISED MANUSCRIPT ReCEIVED APRIL 5, 1995

MANUSCRIPT ACCEPTED APRIL 27, 1995

WOODS HOLE OCEANOGRAPHIC INSTITUTION CONTRIBUTION No. 8852 